\title{
Dynamics of phytoplankton community structure in the South China Sea in response to the East Asian aerosol input
}

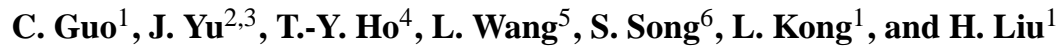 \\ ${ }^{1}$ Division of Life Science, Hong Kong University of Science and Technology, Clear Water Bay, Hong Kong, China \\ ${ }^{2}$ Division of Environment, Hong Kong University of Science and Technology, Clear Water Bay, Hong Kong, China \\ ${ }^{3}$ Department of Chemistry, Hong Kong University of Science and Technology, Clear Water Bay, Hong Kong, China \\ ${ }^{4}$ Research Center for Environmental Changes, Academia Sinica, Taipei, Taiwan \\ ${ }^{5}$ State Key Laboratory of Marine Environmental Science, Xiamen University, Xiamen, China \\ ${ }^{6}$ Key Laboratory of Marine Ecology and Environmental Science, Institute of Oceanology, Chinese Academy of Sciences, \\ Qingdao, China
}

Correspondence to: H. Liu (liuhb@ust.hk)

Received: 21 June 2011 - Published in Biogeosciences Discuss.: 8 July 2011

Revised: 5 April 2012 - Accepted: 6 April 2012 - Published: 26 April 2012

\begin{abstract}
Recent studies have demonstrated atmospheric deposition as an important source of bioreactive compounds to the ocean. The South China Sea (SCS), where aerosol loading is among the highest in the world, however, is poorly studied, particularly on the in situ response of phytoplankton community structures to atmospheric deposition. By conducting a series of microcosm bioassays at different hydrographical locations and simulating different aerosol event scales, we observed both positive and negative responses to the input of East Asian (EA) aerosol with high nitrogen (N) and trace metal contents, in terms of biomass, composition and physiological characteristics of phytoplankton communities. High levels of aerosol loading relieved phytoplankton nitrogen and trace metal limitations in SCS, and thus increased total phytoplankton biomass, enhanced their physiological indicators (e.g. photosynthetic efficiency) and shifted phytoplankton assemblages from being dominated by picoplankton to microphytoplanton, especially diatoms. However, under low levels of aerosol loading, the composition shift and biomass accumulation were not apparent, suggesting that the stimulation effects might be counterbalanced by enhanced grazing mortality indicated by increased abundance of protist grazers. Trace metal toxicity of the aerosols might also be the reason for the reduction of picocyanobacteria when amended with high EA aerosols. The magnitude and duration of the deposition event, as well as the hydrographical and trophic conditions of receiving waters are
\end{abstract}

also important factors when predicting the influence of an aerosol deposition event. Our results demonstrated different responses of phytoplankton and microbial food web dynamics to different scales of atmospheric input events in SCS and highlighted the need for achieving an accurate comprehension of atmospheric nutrient on the biogeochemical cycles of the oceans.

\section{Introduction}

Human activities have profoundly fuelled the generation of industrial and agricultural emissions in the last few decades (Akimoto et al., 2003). These anthropogenic as well as natural sources (e.g. desert and volcano dust), in the form of gases and particles, can be returned to the land and sea via diverse atmospheric depositional processes (Zheng et al., 2005). For example, the biologically active entities may be delivered constantly throughout the year by dry deposition, in a pulse driven by an episodic release, or periodically due to environmental fluctuations. Recent studies have regarded atmospheric aerosol deposition as an increasingly important source of nutrients (macronutrients and trace metals) to the ocean, altering the patterns of the Earth's biogeochemistry (Jickells et al., 2005; Duce et al., 2008). An estimated flux of $67 \mathrm{Tg}$ reactive nitrogen $(\mathrm{N})$, which accounts for up to one third of the ocean's external $\mathrm{N}$ supply, and $16 \mathrm{Tg}$ iron $(\mathrm{Fe})$, 
which is an important source of Fe for the surface waters of open oceans, are contained in the dust depositions, with possible implications on biological productivity (Duce et al., 1991, 2008; Jickells et al., 2005).

Marine biogeochemical cycling and the carbon budget are sensitive to variations in atmospheric nutrient deposition (Martin, 1990; Doney et al., 2007; Krishnamurthy et al., 2007). Recent efforts to understand the biogeochemical role of atmospheric inputs have focused on their impact on ocean primary productivity. It has been showed that aerosol input to the ocean surface is an important forcing that influences the phytoplankton community structure, growth rate, primary and new production (Paerl, 1997; Duce et al., 2008). The atmospheric anthropogenic fixed $\mathrm{N}$ entering open ocean could account for up to $\sim 3 \%$ of the annual new marine biological production (Duce et al., 2008). Enrichment bioassay experiments conducted in the Mediterranean and North Atlantic Ocean using the Saharan dust have demonstrated that dust can relieve the phosphorus (P) and Fe limitations and stimulate $\mathrm{N}$ fixation (Guieu et al., 2002; Ridame and Guieu, 2002; Mills et al., 2004). Atmospheric Fe input can relieve the Fe limitation on primary production occurring in about $30 \%$ of the oceans, especially in the "high-nutrient lowchlorophyll" (HNLC) regions (Martin et al., 1989; Falkowski et al., 1998). Atmospheric deposition has also been suggested to shift the nitrogen/phosphorus (N/P) stoichiometry in oligotrophic oceans (Falkowski, 1997) and lakes (Elser et al., 2009), due to the high N/P ratio in those aerosols (Baker et al., 2003; Paytan et al., 2009). In addition to macronutrients and $\mathrm{Fe}$, the atmospheric supply of other trace metals, such as copper $(\mathrm{Cu})$, zinc $(\mathrm{Zn})$, lead $(\mathrm{Pb})$ and cadmium $(\mathrm{Cd})$, to the ocean is also significant (Duce et al., 1991; Paytan et al., 2009).

The South China Sea (SCS) is one of the largest marginal seas in the world, located in the subtropical and tropical northwest Pacific Ocean. The seawater is oligotrophic, especially in the central basin. The concentrations of $\mathrm{N}$ and $\mathrm{P}$ in the euphotic layer are usually below detection limits, and concentrations of chlorophyll (Chl) $a$ are also low (Gong et al., 1999), with picoplankton dominating the phytoplankton assemblages (Liu et al., 2007). However, the Northwest Pacific region, especially the Chinese marginal seas, is located downwind of East Asian (EA) with large human population densities and high levels of industrial and agricultural activities. The input of $\mathrm{N}, \mathrm{Fe}$ and other trace elements and pollutants to the Northwest Pacific region, through the atmospheric deposition of dust, is among the highest to oligotrophic waters in the world (Duce and Tindale, 1991; Paytan et al., 2009). It has been reported that the atmospheric deposition of dust to the Chinese marginal seas is $67 \mathrm{Tg} \mathrm{yr}^{-1}$, accounting for $14 \%$ of the total atmospheric dust deposition to the entire North Pacific (Gao et al., 1997). As such, this region has become another high-atmospheric-deposition region along with the Mediterranean (e.g. Ridame and Guieu, 2002) and North Atlantic Ocean (e.g. Neuer et al., 2004) that are exposed to Saharan dust. The Asian aerosol is likely to be a complex mixture which not only contains significant amounts of natural mineral dust, but also a substantial portion of anthropogenic polluted aerosols with high concentrations of $\mathrm{N}, \mathrm{Fe}$ and other trace metals, such as combustion-derived ionic, organic and soot particles (Chameides et al., 1999; Cohen et al., 2004; Paytan et al., 2009). These anthropogenic aerosols have a relatively small size, which permits them to have a long life, i.e. from hours to weeks, and being transported for long distances in the range of thousands of kilometers to the SCS, especially in winter when the northeast monsoon prevails (Chameides et al., 1999). Therefore, the unique characteristics and the increasing of the EA aerosol input create an urgency to understand their impact on the Northwest Pacific marine ecosystems.

The effects of atmospheric aerosol loading on phytoplankton community structures and biogeochemistry have been suggested to be significant in this region during previous studies (Wong et al., 2002; Wu et al., 2003; Lin et al., 2007). Assessments based on modelling and remote sensing data indicate that the aerosol loading has a close connection with increased biological production and coastal eutrophication (Lin et al., 2009; Onitsuka et al., 2009; Sundarambal et al., 2010). Paytan et al. (2009) used a model to predict the aerosol toxicity on phytoplankton in the SCS based on theoretical deposition fluxes and toxicity thresholds of phytoplankton. However, there is a lack of field data to reveal the in situ response of the autotrophic assemblages in this region to the input of EA aerosol. To understand the effects of EA aerosol deposition on phytoplankton community structure and production in SCS, we carried out a series of atmospheric aerosol enrichment bioassays using EA aerosol samples and SCS surface seawater to elucidate the following questions: (1) how does EA aerosol affect the phytoplankton in terms of both species composition and physiological characters? (2) Will environmental fluctuations, such as the magnitude and duration of the deposition events, and the hydrographical and trophic conditions of the receiving water modify the response of phytoplankton community to the EA aerosol?

\section{Methods}

\subsection{Atmospheric aerosol collection and treatment}

Aerosol samples were collected locally on the rooftop of the Academic Building at the Hong Kong University of Science and Technology (HKUST). HKUST is located at the eastern side of Hong Kong adjacent to the Port Shelter and SCS. The collection station is in a relatively low populated area and the nearest commercial area is more than $5 \mathrm{~km}$ away. The sampling was conducted on a sunny day in December 2009 when the northeast monsoon prevailed. Fine aerosol particles $\left(\mathrm{PM}_{2.5}\right)$ were collected onto $8 \times 10$-inch Quartz 

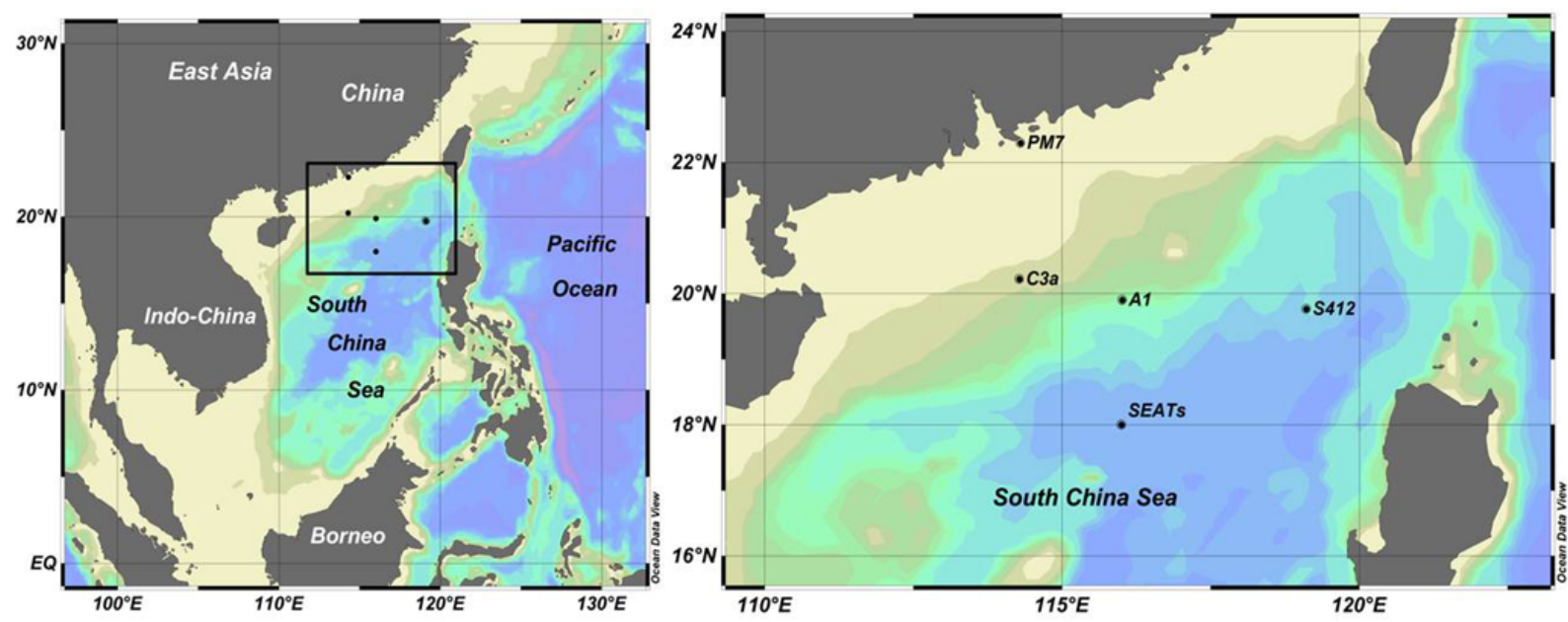

Fig. 1. Locations of the stations where microcosm bioassay experiments were performed.

filters (\#2500 QAT-UP, Pall Life Science, Ann Arbor MI, USA) using a high-volume sampler operated at a flow rate of $11301 \mathrm{~min}^{-1}$ for $24 \mathrm{~h}$. The weight of aerosol on the filter was about $70 \mathrm{mg}$, which was a very rough value estimated using in situ $\mathrm{PM}_{2.5}$ concentration data obtained from the Environmental Central Facility (ENVF/IENV) Atmospheric \& Environmental Database of HKUST (http://envf.ust.hk/dataview/ gts/current/). The sampling height was about $100 \mathrm{~m}$ above sea level. After sample collection, the filters were stored at $-20^{\circ} \mathrm{C}$. Before the cruise, the aerosol filter was dissolved in $450 \mathrm{ml}$ pre-filtered natural seawater (by $0.22 \mu \mathrm{m} \mathrm{PC}$ membrane) collected at station PM7 (Fig. 1), followed by $0.2 \mu \mathrm{m}$ filtration, to make the aerosol leachate. We choose the leaching time of about $1 \mathrm{~h}$ according to previous studies (Martin et al., 1991; Aguilar-Islas et al., 2010; Hsu et al., 2010). The leachate was stored in dark at $4{ }^{\circ} \mathrm{C}$.

\subsection{Study area, seawater collection and experimental design}

The experiments were conducted during December 2009 to January 2010 in Port Shelter, a bay on the east coast of Hong Kong, and during the "Carbon Cycling in China Seas-budget, controls and ocean acidification" (CHOICE-C) cruise in SCS (Fig. 1). Surface seawater was collected by an acid-cleaned bucket and the aliquot (4l) was incubated in acid-cleaned bottles after pre-screening by a $200 \mu \mathrm{m}$ mesh to exclude mesozooplankton. They were immediately amended with aerosols or inorganic nutrients as described in Table 1. The incubations were conducted in an on-deck incubator with temperature controlled by running seawater and covered by two layers of neutral density screen to attenuate the sunlight intensity by $\sim 40 \%$. The bottles were gently stirred twice a day. All experimental treatments were performed in triplicate. The incubation bottles and laboratory wares were soaked in $10 \% \mathrm{HCl}$, thoroughly washed with Milli-Q wa- ter and rinsed with experimental seawater prior to use. The incubation lasted for 72 (for coastal and shelf stations) or 96 (for oceanic stations) hours.

Five microcosm experiments which can be grouped into three kinds of enrichment bioassays (Table 1) were performed at 5 stations (Fig. 1). In Experiment 1, pre-leached atmospheric aerosol was initially enriched in seawater samples with zero (control), low and high concentrations (Table 1) to simulate the episodic atmospheric conditions (e.g., dust storm, typhoon, and heavy rainfall). In the Experiment 2, the aerosol leachate was amended daily with control, low and high aerosol concentrations, using oceanic seawater at station S412, to mimic continuous atmospheric deposition. Experiment 3 was designed to assess the key nutrients in the aerosol that affects phytoplankton growth in SCS. Aerosol leachate as well as inorganic nutrients was added in the seawater collected at station A1 (Table 1). The aerosol concentration used in the Exp 1 was based on the assumption of a low and high deposition event of approximately $1-10 \mathrm{~g} \mathrm{~m}^{-2}$ into the surface ocean with a $50 \mathrm{~m}$-deep mixing layer. It has been shown that the mean annual atmospheric flux of dust over SCS is $43-54 \mathrm{~g} \mathrm{~m}^{-2} \mathrm{yr}^{-1}$ (Zhang et al., 1993; Gao et al., 1997), but the deposition tends to occur in pulses and the flux during dust storm events can be tens to hundreds of times higher than during non-Asian-dust season (Gong et al., 2003; Zhang and Gao, 2007).

\subsection{Subsampling and parameter measurement}

Samples for measurements of picoplankton, heterotrophic protists, and maximum photochemical efficiency of photosystem II (PSII) (Fv/Fm) were taken every $24 \mathrm{~h}$ after nutrient amendments. Other subsamples were removed at the start and end of incubation for analysis of the following parameters: Chl $a$, microplankton (phytoplankton between 20$200 \mu \mathrm{m}$ ), and photosynthetic pigments. 
Table 1. Description of aerosol and inorganic nutrient enrichment experiments.

\begin{tabular}{|c|c|c|c|}
\hline Experiment & Station & Treatment & Addition \\
\hline $\begin{array}{l}\text { Exp 1: Initial aerosol } \\
\text { enrichment bioassay }\end{array}$ & $\begin{array}{l}\text { PM7, C3a, } \\
\text { SEATs }\end{array}$ & $\begin{array}{l}\text { Control } \\
\text { Low } \\
\text { High }\end{array}$ & $\begin{array}{l}\text { None } \\
\text { AL: } 0.5 \mathrm{ml}(\sim 0.076 \mathrm{mg}) \\
\text { AL: } 5.0 \mathrm{ml}(\sim 0.759 \mathrm{mg})\end{array}$ \\
\hline $\begin{array}{l}\text { Exp 2: Daily aerosol } \\
\text { enrichment bioassay }\end{array}$ & S412 & $\begin{array}{l}\text { Control } \\
\text { Low } \\
\text { High }\end{array}$ & $\begin{array}{l}\text { None } \\
\text { AL: } 0.2 \mathrm{ml} \mathrm{d}^{-1}\left(\sim 0.030 \mathrm{mg} \mathrm{d}^{-1}\right) \\
\text { AL: } 2.0 \mathrm{ml} \mathrm{d}^{-1}\left(\sim 0.304 \mathrm{mg} \mathrm{d}^{-1}\right)\end{array}$ \\
\hline $\begin{array}{l}\text { Exp 3: Aerosols and } \\
\text { chemical nutrients } \\
\text { enrichment bioassay }\end{array}$ & A1 & $\begin{array}{l}\text { Control } \\
\text { Aerosol } \\
\mathrm{N}+\mathrm{P} \\
\mathrm{N}+\mathrm{Si} \\
\mathrm{P}+\mathrm{Si}\end{array}$ & $\begin{array}{l}\text { None } \\
\text { AL: } 5.0 \mathrm{ml}(\text { contain } \sim 2.3 \mu \mathrm{M} \text { inorganic } \mathrm{N}) \\
{\left[\mathrm{NH}_{4} \mathrm{NO}_{3}\right] 0.5 \mu \mathrm{M}+\left[\mathrm{PO}_{4}^{3-}\right] 0.1 \mu \mathrm{M}} \\
{\left[\mathrm{NH}_{4} \mathrm{NO}_{3}\right] 0.5 \mu \mathrm{M}+\left[\mathrm{SiO}_{3}^{2-}\right] 1 \mu \mathrm{M}} \\
{\left[\mathrm{PO}_{4}^{3-}\right] 0.1 \mu \mathrm{M}+\left[\mathrm{SiO}_{3}^{2-}\right] 1 \mu \mathrm{M}}\end{array}$ \\
\hline
\end{tabular}

AL: aerosol leachate

\subsubsection{Chl $a$}

Duplicate aliquots of 200-1000 ml subsamples were sequentially filtered through $20 \mu \mathrm{m}$ polycarbonate membranes and Whatman $\mathrm{GF} / \mathrm{F}$ glass fiber filters, which were then extracted with $90 \%$ acetone at $-20{ }^{\circ} \mathrm{C}$ in the dark overnight and determined fluorometrically using a Turner Designs Trilogy fluorometer (Strickland and Parsons, 1972).

\subsubsection{Fv/Fm}

The maximum photochemical efficiency of PSII (Fv/Fm) was determined by a Fluorescence Induction and Relaxation (FIRe) System (Satlantic Inc.). Samples were dark adapted for $30 \mathrm{~min}$ at in situ temperatures before measurement. Data collection and processing were conducted following the manufacturer's protocols.

\subsubsection{Inorganic nutrients}

Samples for measurement of inorganic nutrients in the aerosol seawater leachate (nitrate, nitrite, ammonium, phosphate and silicate) were filtered through $\mathrm{GF} / \mathrm{F}$ glass fiber filters, and the filtrates immediately frozen at $-20^{\circ} \mathrm{C}$ until analysis. The concentrations of inorganic nutrients were determined colorimetrically using a Skalar autoanalyzer (San Plus) following JGOFS protocols (Knap et al., 1996). The data of in situ inorganic nutrient concentrations at each station (Table 2) were provided by M. Dai et al. (unpublished data).

\subsubsection{Trace metal measurements}

The trace metal concentrations in the aerosol leaching solution were determined. The leachate samples were diluted 100- to 1000-fold with $3 \%$ super-pure nitric acid (Seastar) with Element grade Milli-Q water in a class 100 tracemetal clean bench, which were ready for inductively cou- pled plasma mass spectrometer (ICPMS) analysis. The concentrations of all trace metals analyzed were determined by using a sector field double-focusing high-resolution ICPMS (Element XR, Thermo Scientific), fitted with a de-solvation system (APEX and Spiro, Elemental Scientific Inc.). The sensitivity and stability of the instrument was adjusted to optimal condition before analysis. The analysis was conducted with sensitivity above $10^{6}$ counts per second for $1 \mathrm{ppb}$ indium standard and the analytical precision was normally between $1 \%$ and $2 \%$. External and internal standards were both applied for concentration quantification. The details of the analytical accuracy and detection limits of the ICPMS method are described in Ho et al. (2007).

\subsubsection{Microphytoplankton identification}

One hundred milliliter subsamples for enumeration of microplankton were collected at station PM7, C3a, SEATs, and S412, fixed with acidic Lugol's solution (final concentration $5 \%$ ), and stored in amber plastic bottles at room temperature for microscopic observation. Samples of 10-30 ml were concentrated by settling for $24 \mathrm{~h}$ in glass cylinders. Microplankton were identified and counted under an Olympus IX51 inverted microscope.

\subsubsection{Picoplankton and heterotrophic nanoflagellate (HNF) enumeration}

Autotrophic picoplankton and HNF were enumerated using a Becton-Dickson FACSCalibur Flow Cytometer under high flow rate of $60 \mu \mathrm{min}^{-1}$. Samples $(1.8 \mathrm{ml})$ were fixed with $0.5 \%$ seawater buffered paraformaldehyde and stored at $-80^{\circ} \mathrm{C}$ before analysis. Abundances of picoplankton (Prochlorococcus, Synechococcus, and picoeukaryotes) were discriminated according to the side scattering (SSC) and red/orange auto-fluorescences emitted by chlorophyll/phycoerythrin (Olson et al., 1993). For counting 
Table 2. Initial conditions for bioassay experiments.

\begin{tabular}{|c|c|c|c|c|c|}
\hline Station & PM7 & $\mathrm{C} 3 \mathrm{a}$ & SEATs & A1 & S412 \\
\hline Sampling date & $11 / 12 / 2009$ & 08/01/2010 & $12 / 01 / 2010$ & $17 / 01 / 2010$ & $23 / 01 / 2010$ \\
\hline Type of location & coastal & continental shelf & oceanic & continental slope & oceanic \\
\hline Bottom depth (m) & 17 & 137 & 3844 & 854 & 3340 \\
\hline Surface temperature $\left({ }^{\circ} \mathrm{C}\right)$ & 25.40 & 22.82 & 24.66 & 23.27 & 24.27 \\
\hline Salinity (psu) & 34.30 & 34.06 & 33.72 & 34.07 & 33.80 \\
\hline $\mathrm{NO}_{2}^{-}+\mathrm{NO}_{3}^{-}\left(\mu \mathrm{moll}^{-1}\right)$ & 1.020 & 0.609 & $<0.100$ & 0.244 & $<0.100$ \\
\hline $\mathrm{PO}_{4}^{3-}\left(\mu \mathrm{mol} 1^{-1}\right)$ & 0.120 & $<0.080$ & $<0.080$ & 0.082 & $<0.080$ \\
\hline $\mathrm{SiO}_{3}^{2-}\left(\mu \mathrm{mol} 1^{-1}\right)$ & 2.550 & 1.504 & 2.406 & 1.175 & 1.750 \\
\hline$[\mathrm{Chl} a>20 \mu \mathrm{m}]\left(\mu \mathrm{g} 1^{-1}\right)$ & $0.161(0.020)$ & $0.041(0.003)$ & $0.004(0.001)$ & $0.032(0.004)$ & $0.035(0.001)$ \\
\hline$[\mathrm{Chl} a<20 \mu \mathrm{m}]\left(\mu \mathrm{g} 1^{-1}\right)$ & $0.289(0.045)$ & $0.268(0.003)$ & $0.077(0.011)$ & $0.248(0.044)$ & $0.427(0.020)$ \\
\hline [Chl $a$ total $]\left(\mu \mathrm{g} 1^{-1}\right)$ & $0.450(0.065)$ & $0.309(0.001)$ & $0.081(0.013)$ & $0.281(0.041)$ & $0.462(0.022)$ \\
\hline$[>20 \mu \mathrm{m} \mathrm{Chl} a] \%$ & $36 \%$ & $13 \%$ & $5 \%$ & $11 \%$ & $8 \%$ \\
\hline $\begin{array}{l}\text { Prochlorococcus } \\
\left(10^{3} \text { cells }^{-1}\right)\end{array}$ & 0 & $40.73(0.27)$ & $178.50(6.55)$ & $21.24(1.16)$ & $23.58(1.95)$ \\
\hline $\begin{array}{l}\text { Synechococcus } \\
\left(10^{3} \text { cells } \mathrm{ml}^{-1}\right)\end{array}$ & 93.69 & $46.98(0.80)$ & $14.18(0.14)$ & $25.58(0.32)$ & $49.75(1.70)$ \\
\hline $\begin{array}{l}\text { Picoeukaeyotes } \\
\left(10^{3} \text { cells } \mathrm{ml}^{-1}\right)\end{array}$ & 5.30 & $5.58(0.23)$ & $3.23(0.12)$ & $5.15(0.02)$ & $11.55(0.96)$ \\
\hline $\mathrm{HNF}\left(\right.$ cells ml $^{-1}$ ) & $609(0)$ & $341(0)$ & $426(16)$ & $322(36)$ & $336(39)$ \\
\hline
\end{tabular}

The numbers in parenthesis are standard errors of the mean. HNF: heterotrophic nanoflagellates

the heterotrophic nanoflagellate (HNF), the samples were stained with $0.01 \%$ SYBR Green I (Invitrogen) and then incubated under $37^{\circ} \mathrm{C}$ for $40 \mathrm{~min}$. The method for HNF enumeration was according to Zubkov et al. (2007). Yellowish green fluoresence beads ( $1 \mu \mathrm{m}$, Polysciences) were added as an internal standard. Flow cytometric data were analyzed using WinMDI software 2.9 (Joseph Trotter, Scripps Research Institute, La Jolla, CA, USA). The values of SSC signal and red fluorescence emission were normalized to beads, and used as the proxy of cell size and cellular Chl $a$.

\subsubsection{Pigment analysis by high-performance liquid chromatography (HPLC)}

Seawater samples (1.9-61) for pigment analysis were filtered onto $25 \mathrm{~mm}$ Whatman $\mathrm{GF} / \mathrm{F}$ filters under a gentle vacuum $(<0.2 \mathrm{MPa})$ at station C3a, SEATs, A1 and S412. Filters were wrapped in aluminum foil and stored at $-80^{\circ} \mathrm{C}$. The pigment concentrations were detected using High Performance Liquid Chromatography (HPLC) following the modified method of Furuya et al. (1998). The filter was soaked in $2 \mathrm{ml} N, N$-dimethylformamide (DMF) extraction at $-20^{\circ} \mathrm{C}$ for $2 \mathrm{~h}$. The extraction was then filtered through $13 \mathrm{~mm}$ Whatman GF/F filters (Swinnex Filter Holder) to clean the debris and mixed with $1 \mathrm{moll}^{-1}$ ammonium acetate $(600: 600 \mu \mathrm{l})$. Each mixture was partially injected into an Agilent series 1100 HPLC system fitted with a $3.5 \mu \mathrm{m}$ Eclipse XDB $\mathrm{C}_{8}$ column $(100 \times 4.6 \mathrm{~mm}$; Agilent Technologies). Quantification was confirmed by the standards that were purchased from Danish Hydraulic Institute [DHI] Water and Environment, Hørsholm, Denmark.

\subsubsection{Statistical analyses}

One-way ANOVA was conducted to assess if the differences in selected parameters were significant among different treatments and controls using SPSS.

\section{Results}

\subsection{Characteristics of surface seawaters and aerosol samples}

The sampled seawater used for experiments was oligotrophic as indicated by low Chl $a$ and macronutrient concentrations (Table 2). Concentrations of inorganic $\mathrm{N}$ were below $1.1 \mu \mathrm{mol}^{-1}$, decreasing from the coastal station PM7, to continental shelf or slope stations $\mathrm{C} 3 \mathrm{a}$ and $\mathrm{A} 1$, and to oceanic stations SEATs and S412. Initial P concentrations were below the detection limit $\left(0.08 \mu \mathrm{moll}{ }^{-1}\right)$ at all the stations except PM7 and A1. Low Chl $a$ concentrations $\left(<0.5 \mu \mathrm{g} \mathrm{l}^{-1}\right)$ were observed, with a declining trend along the onshoreoffshore gradient. Generally, pico- $(0.2-2 \mu \mathrm{m})$ and nanosized $(2-20 \mu \mathrm{m})$ phytoplankton dominated in total Chl $a$ at all stations (64-95\%). The contribution of micro-sized cells $(>20 \mu \mathrm{m})$ decreased from onshore to offshore stations, ranging from $\sim 35.7 \%$ at PM7 and $\sim 13.1 \%$ at $\mathrm{C} 3 \mathrm{a}$, to $\sim 4.76 \%$ at SEATs. 
Table 3. Concentration of trace metal element and macro-nutrient in the aerosol leachate, and estimated enrichment in the High and Low treatments of Experiment 1.

\begin{tabular}{|c|c|c|c|c|c|c|c|c|c|c|c|c|c|c|c|}
\hline & \multicolumn{4}{|c|}{ macro-nutrient } & \multicolumn{11}{|c|}{ trace metal elements } \\
\hline & $\mathrm{SiO}_{3}$ & $\mathrm{NH}_{4}$ & $\mathrm{NO}_{3}+\mathrm{NO}_{2}$ & $\mathrm{PO}_{4}$ & $\mathrm{Cd}$ & $\mathrm{Pb}$ & $\mathrm{Al}$ & V & $\mathrm{Cr}$ & $\mathrm{Mn}$ & $\mathrm{Fe}$ & Co & $\mathrm{Ni}$ & $\mathrm{Cu}$ & $\mathrm{Zn}$ \\
\hline $\begin{array}{l}\text { aerosol leachate } \\
(\mu \mathrm{M})\end{array}$ & 630.9 & 1639.8 & 237.9 & 7.980 & 0.091 & 1.470 & 7.620 & 0.530 & 0.076 & 1.229 & 2.960 & 0.009 & 0.194 & 3.378 & 16.182 \\
\hline $\begin{array}{l}\text { High treatment } \\
(\mathrm{nM})\end{array}$ & 788.6 & 2049.7 & 297.3 & 9.975 & 0.114 & 1.838 & 9.525 & 0.662 & 0.095 & 1.537 & 3.700 & 0.011 & 0.243 & 4.223 & 20.227 \\
\hline $\begin{array}{l}\text { Low treatment } \\
\text { (nM) }\end{array}$ & 78.9 & 205.0 & 29.7 & 0.998 & 0.011 & 0.184 & 0.952 & 0.066 & 0.009 & 0.154 & 0.370 & 0.001 & 0.024 & 0.422 & 2.023 \\
\hline
\end{tabular}
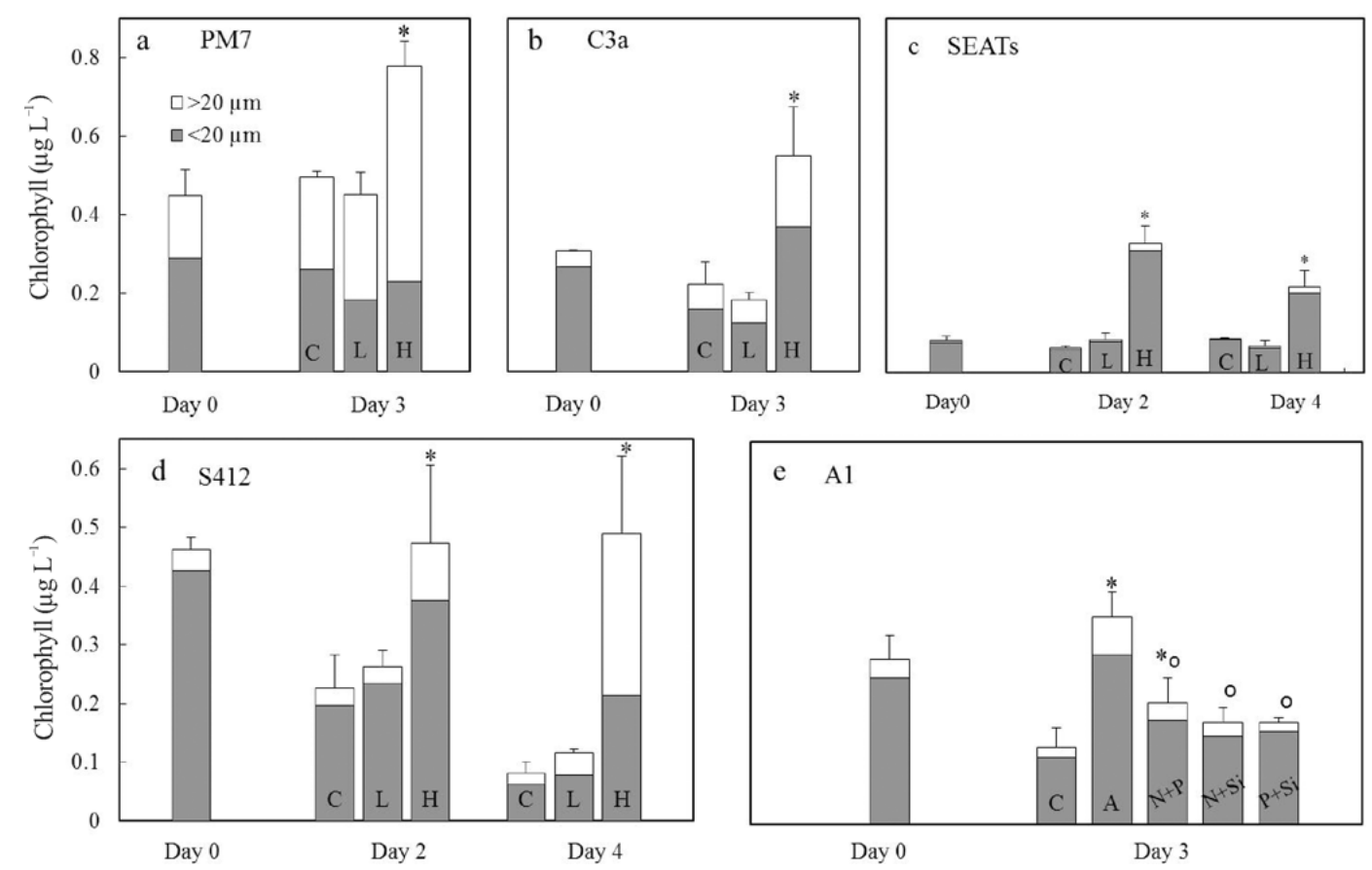

Fig. 2. Response of Chl $a$ concentrations in the SCS to the addition of EA aerosols and inorganic nutrients in (a-c) Experiment 1, (d) Experiment 2, and (e) Experiment 3. Error bars represent the standard deviation of total Chl $a$ concentration from triplicate incubations. Asterisks indicate statistically significant mean Chl $a$ values $(p<0.05)$ of treatments compared with the corresponding controls on the same day. Circles in (e) indicate significant mean Chl $a$ values $(p<0.05)$ of treatments compared with treatment A on day 3. C: Control; L: Low treatment; H: high treatment; A: aerosol treatment (see Table 1).

As the dominant phytoplankton fraction in SCS, the three major groups of picophytoplankton distributed differently. Synechococcus abundance ranged from $1.4 \times 10^{4}$ to $9.0 \times 10^{4}$ cells ml $^{-1}$ and was most abundant in coastal and continental shelf waters; Prochlorococcus was not found at the coastal station (PM7) and its highest abundance $\left(1.8 \times 10^{5}\right.$ cells ml$\left.^{-1}\right)$ occurred at the oligotrophic, oceanic station SEATS; and picoeukaryote abundance ranged from $3.2 \times 10^{3}-1.1 \times 10^{5}$ cells ml $^{-1}$ (Table 2 ).

The elements and compounds released from the EA aerosol samples are shown in Table 3. The aerosol leachate contained a significant amount of seawater leachable $\mathrm{N}$ as well as various trace metal elements, especially $\mathrm{Pb}, \mathrm{Zn}, \mathrm{Cu}$, and Fe. The leachable N/P ratio was about 235, almost 15 times higher than the Redfield ratio.

\subsection{Phytoplankton size shifts characterized by $\mathrm{Chl} a$ concentrations}

Addition of atmospheric aerosol leachate induced an increase of total Chl $a$ and shifted the size structure of phytoplankton across all experiments during the 3 or 4-day of on-deck incubations (Fig. 2). The responses of total Chl $a$ to the onetime initial aerosol additions were highly consistent at all 3 stations (Experiment 1; Fig. 2a-c). In the High treatment, total Chl $a$ concentrations increased significantly by $1.6,2.5$ and 3.5-fold compared to the control values, with 2.3, 2.9 
and 5.6-fold increases for the micro-sized cells and 0.9, 2.3 and 3.4-fold increases for the pico- and nano-sized cells at coastal station PM7, shelf station C3a and oceanic station SEATs, respectively. In contrast to high aerosol additions, low aerosol amendments did not result in significant change of Chl $a$ concentrations at all three stations. Compared with Experiment 1, a more dramatic accumulation of total Chl $a$ and phytoplankton size shifts were found in the High treatment in Experiment 2, in which aerosol leachate was added daily during the incubation period (Fig. 2d). The concentration of total Chl $a$ was enhanced 5.5-fold, with micro-sized cells increasing 14.7-fold relative to the control. The Chl $a$ concentration in the Low treatment also showed a slight increase compared with control, which is different from Experiment 1. In Experiment 3, the addition of aerosol leachate resulted in a larger increase in Chl $a$ concentration, when compared with the control and other 3 treatments (Fig. 2e). A smaller increase was observed in the $\mathrm{N}+\mathrm{P}$ treatment during the 3-day incubation compared with the control. No significant differences were observed between control bottles and those enriched with $\mathrm{N}+\mathrm{Si}$ and $\mathrm{P}+\mathrm{Si}$. Chl $a$ concentrations measured by fluorometry were consistent to those obtained by HPLC.

\subsection{Phytoplankton assemblage shifts characterized by phytopigments}

In addition to size-fractioned Chl $a$, a further 18 different types of pigments were analyzed by HPLC to determine the contribution of different phytoplankton communities in response to aerosol amendments. Changes in 13 typical phytoplankton marker chlorophylls and carotenoids are demonstrated in Fig. 3. A remarkable increase of fucoxanthin, the marker pigment for diatoms, could be clearly observed at C3a, S412 and A1 in the High treatments (Fig. 3a, c, d). Shifts in the phytoplankton community composition were also revealed by different degrees of increases in some minor phytoplankton groups as indicated by their marker pigments, such as peridinin, $\mathrm{Chl} c 2$, diadinoxanthin and $\beta$-carotene (dinoflagellates), 19'-hexanoyloxyfucoxanthin (prymnesiophytes including coccolithophores and some picoeukaryotes), neoxanthin and $\mathrm{Chl} b$ (green algae). In the Low treatments, significant change did not occur compared with the control. On the other hand, zeaxanthin, the marker pigment of cyanobacteria (including Prochlorococcus and Synechococcus), was the only pigment that decreased or remained unchanged in the High treatment at C3a and S412 (Fig. 3a, c). In Experiment 2, the daily aerosol enrichment induced a more remarkable increase of some pigments, such as neoxanthin (15.6-fold increase compared with control) and fucoxanthin (7.8-fold increase compared with control) in the High treatment (Fig. 3c). In Experiment 3, most phytopigments showed the strongest positive response to aerosol addition, and the second strongest reaction to $\mathrm{N}+\mathrm{P}$ enrichment (Fig. 3d).

\subsection{Group specific responses of picophytoplankton}

Picoplankton populations of Prochlorococcus, Synechococcus and picoeukaryotes did not respond uniformly to the EA aerosol leachate (Fig. 4). The abundance of Prochlorococcus and Synechococcus only displayed small increases or did not change in the Low treatments, while they showed either no change or a decrease in the High treatments when compared with the control at most stations (Fig. 4a, b, d, f, h). However, at oceanic station SEATs, the responses of Prochlorococcus and Synechococcus in the High treatment were significant with approximately a 2-fold increase when compared with the control (Fig. 4c, g). These results are consistent with the change of zeaxanthin concentrations measured by HPLC (Fig. 3). The abundance of picoeukaryotes showed increases in both the Low and High treatments during incubation at SEATs and S412, but only in the High treatment at PM7 and C3a (Fig. 4j-m).

The comparison of picoplankton responses to various nutrient species also indicated different nutrient requirements between groups as presented in Experiment 3 (Fig. 4e, i, n). Significant increases in the abundance of Prochlorococcus and Synechococcus were observed in the aerosol and $\mathrm{N}+\mathrm{P}$ treatments. For picoeukaryotes, all four treatments induced a higher abundance when compared with the control, with the addition of aerosol and $\mathrm{N}$ in combination with $\mathrm{P}$ or $\mathrm{Si}$ resulting in larger increases.

\subsection{Group specific responses of microphytoplankton and HNF}

Total microphytoplankton abundance increased significantly by 3.8, 1.7, and 1.8-fold respectively at PM7, C3a and SEATs in Experiment 1, and 9.1-fold at S412 in Experiment 2 after high aerosol addition (Fig. 5). Diatoms were dominant in the assemblage, with 4.1, 1.7, 2.0-fold increases after high aerosol addition at PM7, C3a and SEATs respectively in Experiment 1, and 9.4-fold at S412 in Experiment 2. Chaetoceros spp., Pseudonitzchia spp., Guinardia spp., Thalassionema spp., and Skeletonema spp. were the dominant species of diatoms, and their abundances were strongly promoted by the aerosol additions (Fig. 5).

The protist grazers exhibited significant increases after addition of aerosol. The abundance of HNF increased by about 1.3- and 1.8-fold on average respectively in the Low and High treatment in Experiment 1 and 2 (Fig. 6a-d). In Experiment 3 , the abundance of $\mathrm{HNF}$ increased significantly by 2, 1.9, 1.6-fold in the aerosol, $\mathrm{N}+\mathrm{P}$ and $\mathrm{N}+\mathrm{Si}$ treatment, respectively (Fig. 6e).

\subsection{Physiological characters}

Statistically significant physiological changes were observed after aerosol enrichment incubations. These changes included enhancement of photosynthetic efficiency and an 


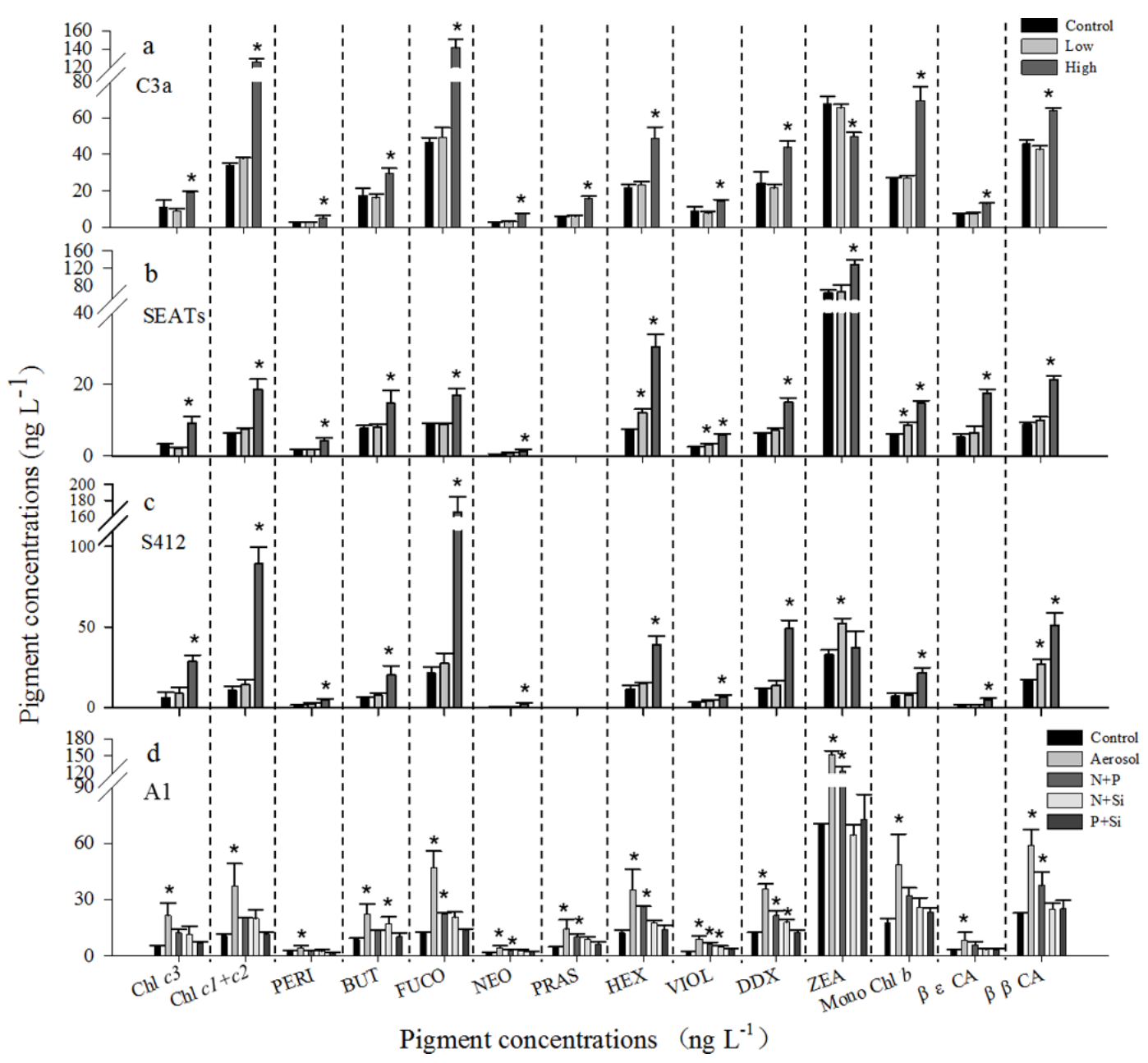

Fig. 3. Responses of 14 phytopigments to aerosol and inorganic nutrient enrichment at (a) C3a and (b) SEATs of Experiment 1, (c) S412 of Experiment 2, and (d) A1 of Experiment 3. Error bars represent the standard deviation of pigment concentration from triplicate incubations. Asterisks indicate statistically significant mean values $(p<0.05)$ compared with the controls. Chl $c 3$ : chlorophyll $c 3$; Chl $c 1+c 2$ : chlorophyll $c 1+c 2$; PERI: peridinin; BUT: 19'-butanoyloxyfucoxanthin; FUCO: fucoxanthin; NEO: neoxanthin; PRAS: prasinoxanthin; HEX: 19'-hexa-noyloxyfucoxanthin; VIOL: violaxanthin DDX: diadinoxanthin; ZEA: zeaxanthin; Mono Chl $b$ : monovinyl chlorophyll $b$; $\beta \varepsilon$ CA: $\beta, \varepsilon$-carotene; $\beta \beta \mathrm{CA}: \beta, \beta$-canrotene.

increase of cellular and community biomass as indicated by enhanced cytometric signal of side scatter and red fluorescence signal (Fig. 7-8). The Fv/Fm ratio, which was driven by phytoplankton community structure as well as nutrient stress (Olaizola et al., 1996; Suggett et al., 2009), showed higher values in the High treatment at stations PM7 and S412 compared with the controls (Fig. 7). Enhancement of side scatter and Chl $a$ fluorescence was observed across most experiments for Prochlorococcus and Synechococcus after high aerosol addition (Fig. 8b, d), whereas no significant differences were found between most of the Low treatments and the controls (Fig. 8a, c). On the contrary, for picoeukaryotes, the relative changes of side scatter and red fluorescence were negative after aerosol addition at most stations (Fig. 8).

\section{Discussion}

\subsection{Unique features of the EA aerosol}

The atmospheric aerosol deposition is a significant nutrient source to marine ecosystems, and the aerosol from different origins are diverse in composition and size ranges. Studies that investigated the effect of aerosol input on marine ecosystems in different regions using enrichment bioassay methods have been conducted in the Red Sea, Mediterranean Sea, North Atlantic Ocean and high mountain lakes using Saharan dust or European aerosols in recent years, as summarized in Table 4. It is demonstrated that regional variations of atmospheric deposition may have a significant impact on the spatial patterns of phytoplankton assemblages and biogeochemical cycles. For example, the Saharan aerosol which is 

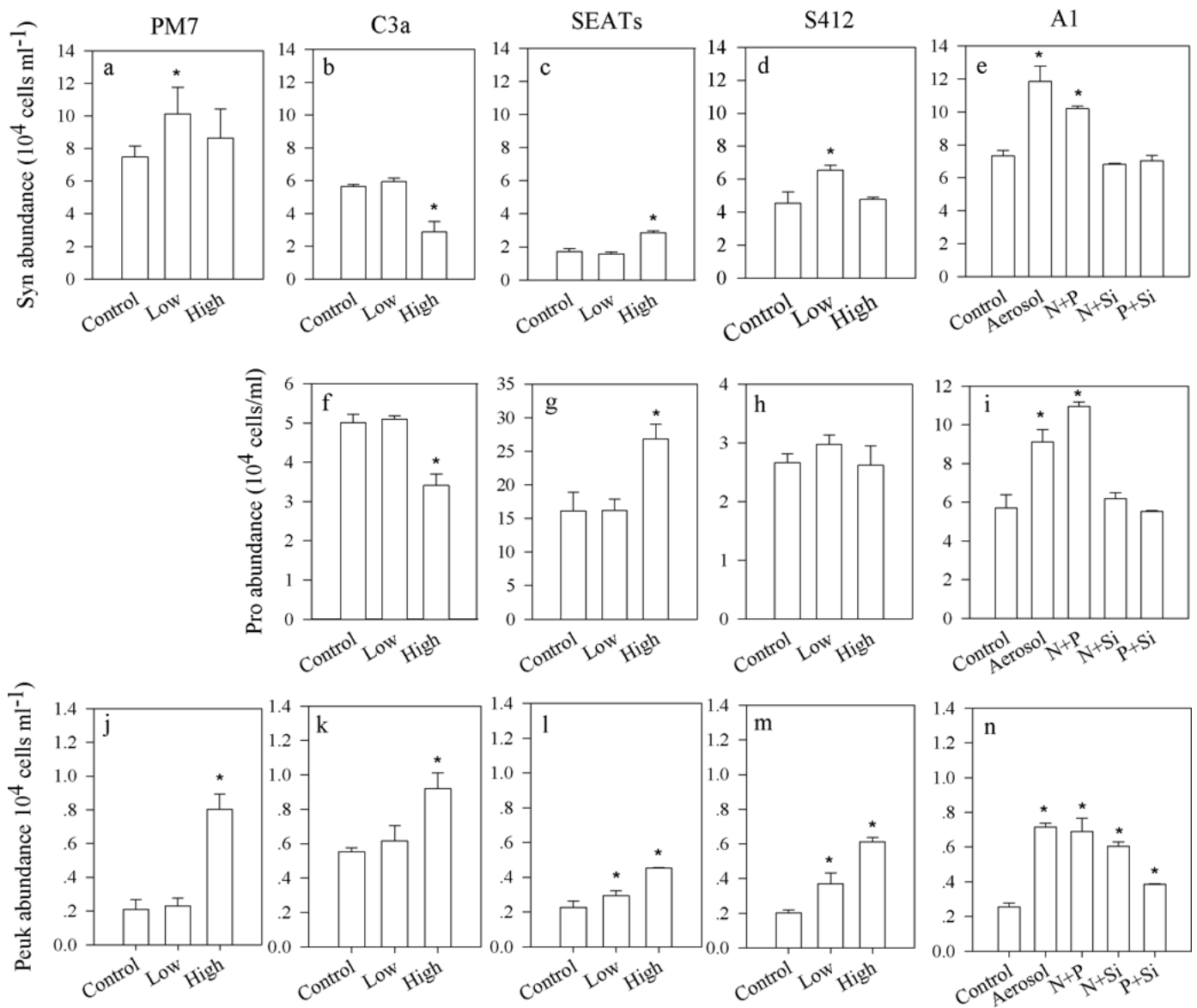

Fig. 4. Response of picoplankton abundances to the EA aerosol enrichment. The abundances of (a-e) Synechococcus (Syn), (f-i) Prochlorococcus (Pro), and (j-n) picoeukaryotes (Peuk) in control, Low or High treatment at $72 \mathrm{~h}$ were shown. Error bars represent the standard deviation of the abundance from triplicate incubations. Asterisks indicate statistically significant mean values $(p<0.05)$ compared with the controls.
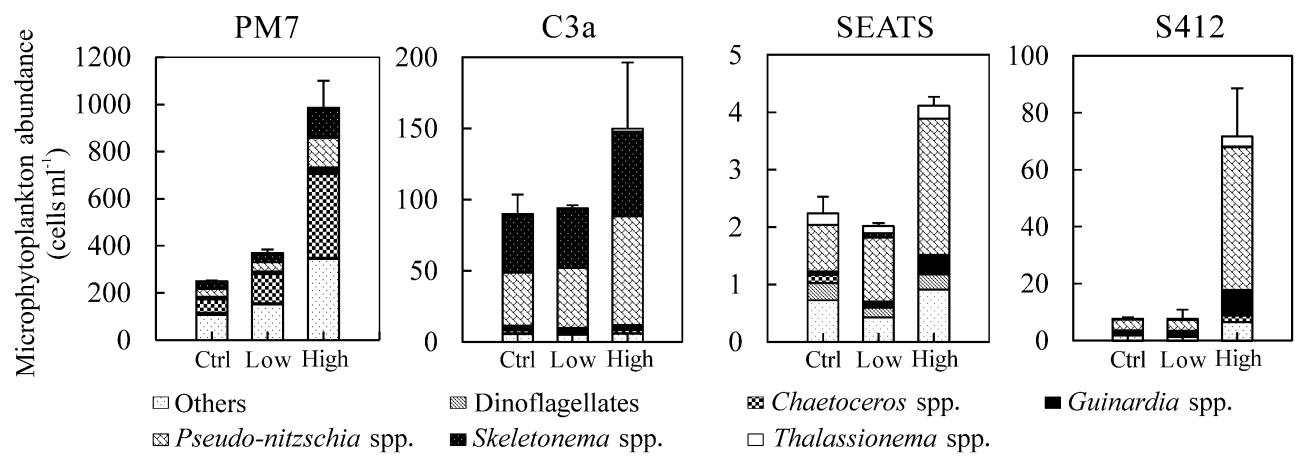

Fig. 5. Response of microphytoplankton species abundances to the EA aerosol enrichment at (a) PM7, (b) C3a and (c) SEATs of Experiment 1, and (d) S412 of Experiment 2. Error bars represent the standard deviation of total microphytoplankton abundance from triplicate incubations. Asterisks indicate statistically significant mean values $(p<0.05)$ of total microphytoplankton abundance compared with the controls.

originated from Sahara desert and carried over to the western Mediterranean Sea was reported to be coarse in grain size, and served as an important source of soluble $\mathrm{P}$ to the West Mediterranean region (Ridame and Guieu, 2002). By relieving the $\mathrm{P}$ and/or Fe limitation, addition of $500 \mathrm{mg}^{-1}$ Sahara dust induced an increase of 3.3-10 fold of total Chl $a$ in coastal Mediterranean, and addition of $4.88 \mathrm{mg} \mathrm{l}^{-1}$ lead 

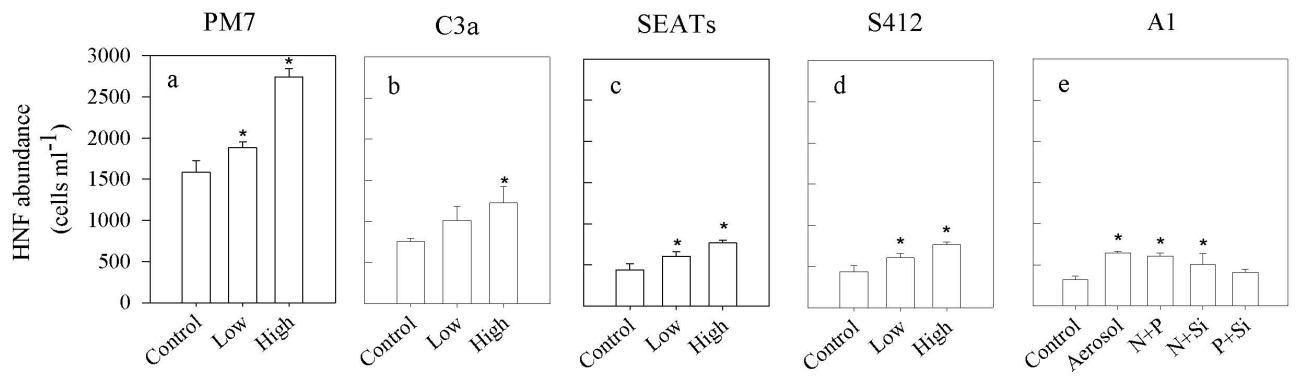

Fig. 6. Response of heterotrophic nanoflagellates (HNF) to the EA aerosol enrichment in (a-c) Experiment 1, (d) Experiment 2, and (e) Experiment 3. The abundances were measured at $72 \mathrm{~h}$. Error bars represent the standard deviation from triplicate incubations. Asterisks indicate statistically significant mean values $(p<0.05)$ compared with the controls.
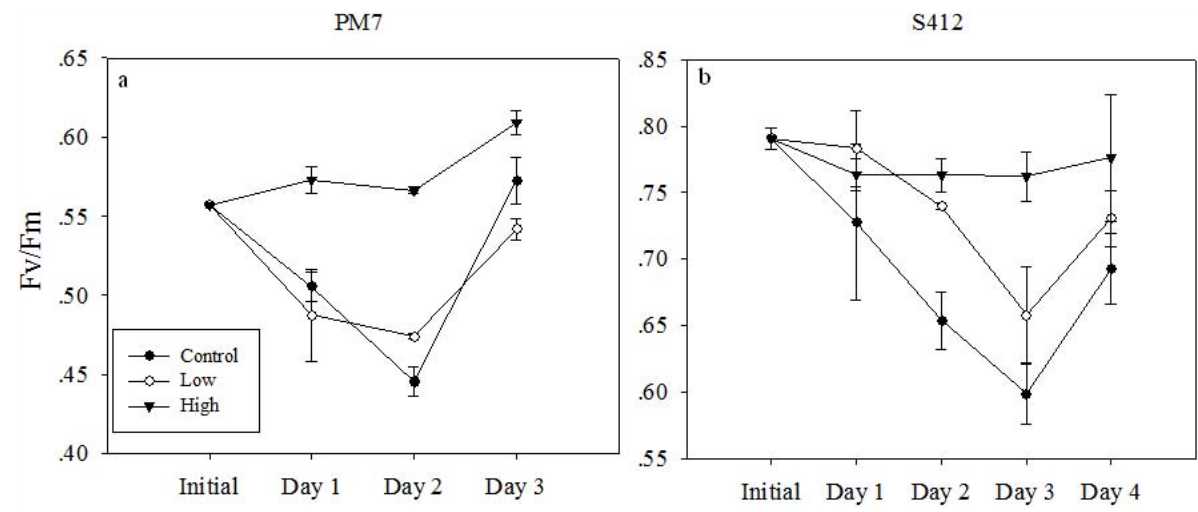

Fig. 7. Responses of phytoplankton photochemical quantum efficiency (Fv/Fm) at (a) PM7 of exp 1 and (b) S412 of exp 2 . Error bars represent the standard deviation from triplicate incubations.

to 4.76-fold increase of Chl $a$ in ultraoligotrophic Eastern Mediterranean basin (Table 4).

Compared with Sahara dust, the EA aerosol has a much broader fine-size mass distribution contributed by industrial sources along the Chinese coast (Duce et al., 1991; Chameides et al., 1999; Cohen et al., 2004). Also, the long distance transportation from landmass to the SCS favors smallsized particles over larger particles (Duce et al., 1991). It has been reported that fine particles dominate the coarse particle over the Northern SCS (Zhang et al., 2007). The relative chemical composition of the soluble nutrients and trace metal elements in our study is consistent with the chemical composition of the aerosols over SCS and other EA aerosols reported in previous studies, which are characterized by relatively higher concentrations of nitrate and ammonium than phosphate, and relatively higher concentrations of $\mathrm{Al}, \mathrm{Fe}, \mathrm{Pb}$, $\mathrm{Cu}, \mathrm{Mn}, \mathrm{Zn}$ than other trace metals listed in Table 2 (Cohen et al., 2004; Zhang et al., 2007). In our study, 1.6, 2.5 and 3.5-fold increases of total $\mathrm{Chl} a$ were obtained respectively in coastal, shelf and oceanic station in SCS with addition of only $0.19 \mathrm{mg} \mathrm{l}^{-1}$ EA aerosol (High treatment in Exp 1). Although the aerosol we used was smaller and thus contained higher nutrient content per weight, this amount of EA aerosol addition was approximately 25-2631 fold lower than the en- richment doses of Sahara dust in Mediterranean Sea in previous studies (Table 4), indicating the strong ability of EA aerosols in stimulating phytoplankton biomass accumulation due to its anthropogenic nature.

\subsection{Positive and negative responses of bulk phytoplankton biomass to aerosol addition}

It has been suggested that, in the oligotrophic SCS, phytoplankton growth is limited by nutrient availability, especially $\mathrm{N}$ and Fe (Wu et al., 2003; Chen et al., 2004). During this cruise, N/P ratios less than 16 were observed at most of the stations, supporting the point that $\mathrm{N}$ was relatively limiting in this ecosystem (M. Dai et al., unpublished data). In our Experiment 3, Chl $a$ in treatments with $\mathrm{N}(\mathrm{N}+\mathrm{P} / \mathrm{Si}$ treatment $)$ did not show significant increase compared with treatment without $\mathrm{N}(\mathrm{P}+\mathrm{Si}$ treatment), indicating that $\mathrm{N}$ alone did not play a critical role in promoting $\mathrm{Chl} a$ accumulation. However, the increase of biomass induced by adding aerosol was far more than that induced by the combination of $\mathrm{N}, \mathrm{P}$ and $\mathrm{Si}$, which inferred the high level of trace metals released by the aerosol, especially $\mathrm{Fe}$, together with $\mathrm{N}$, as the most probable reason for the pulse of biomass in the aerosol treatments. It has been reported that the Fe concentration in SCS was 
Table 4. Recent studies of the effect of aerosol input on marine ecosystems in different regions using the enrichment bioassay method.

\begin{tabular}{|c|c|c|c|c|c|c|c|c|c|c|c|}
\hline \multirow[t]{3}{*}{ Region } & \multirow{3}{*}{$\begin{array}{l}\text { Hydrotrophic } \\
\text { features }\end{array}$} & \multirow[t]{3}{*}{ Material } & \multirow{3}{*}{$\begin{array}{l}\text { Addition } \\
\left(\mathrm{mg} \mathrm{l}^{-1}\right)\end{array}$} & \multirow{3}{*}{$\begin{array}{l}\text { Chl } \\
\text { response }\end{array}$} & \multicolumn{5}{|c|}{ Response of autotrophic communities } & \multirow[t]{3}{*}{ Explanation } & \multirow[t]{3}{*}{ Reference } \\
\hline & & & & & \multicolumn{3}{|c|}{ Pico abund. } & \multirow{2}{*}{$\begin{array}{l}\text { Micro- } \\
\text { abund. }\end{array}$} & \multirow{2}{*}{$\begin{array}{l}\text { Nano- } \\
\text { abund. }\end{array}$} & & \\
\hline & & & & & Pro & Syn & Peuk & & & & \\
\hline \multirow[t]{2}{*}{ Red Sea } & \multirow{2}{*}{$\begin{array}{l}\text { oligo- to } \\
\text { mesotrophic; N, } \\
\text { P co-limitation }\end{array}$} & $\begin{array}{l}\text { European } \\
\text { aerosol }\end{array}$ & 0.75 & $\uparrow>2$-fold & $\rightarrow$ & $\uparrow$ & $\uparrow$ & & & \multirow{2}{*}{$\begin{array}{l}\text { Aerosol can in- } \\
\text { duce both fertil- } \\
\text { ization effect }(\mathrm{N} \\
\text { and } \mathrm{P}) \text { and toxi- } \\
\text { city effect }(\mathrm{Cu})\end{array}$} & \multirow{2}{*}{$\begin{array}{l}\text { Paytan } \\
\text { et al. } \\
(2009)\end{array}$} \\
\hline & & $\begin{array}{l}\text { African } \\
\text { aerosol }\end{array}$ & 0.75 & $\downarrow$ & $\rightarrow$ & $\downarrow$ & $\downarrow$ & & & & \\
\hline \multirow[t]{2}{*}{$\begin{array}{l}\text { Eastern } \\
\text { Mediterranean }\end{array}$} & \multirow[t]{2}{*}{$\begin{array}{l}\text { ultra- } \\
\text { oligotrophic }\end{array}$} & $\begin{array}{l}\text { Fresh Sahara } \\
\text { dust }\end{array}$ & 4.88 & $\uparrow 4.76$-fold & $\downarrow$ & $\uparrow$ & $\downarrow$ & $\rightarrow$ & $\downarrow$ & \multirow{2}{*}{$\begin{array}{l}\text { Nutrient re- } \\
\text { leased from } \\
\text { dust triggered } \\
\text { the primary } \\
\text { production } \\
\text { enhancement }\end{array}$} & \multirow{2}{*}{$\begin{array}{l}\text { Herut } \\
\text { et al. } \\
(2005)\end{array}$} \\
\hline & & $\begin{array}{l}\text { Pre-leached } \\
\text { dust }\end{array}$ & $4.75-4.94$ & $\rightarrow$ & $\downarrow$ & $\uparrow$ & $\downarrow$ & $\downarrow$ & $\downarrow$ & & \\
\hline \multirow{2}{*}{$\begin{array}{l}\text { Mediterranean } \\
\text { coast }\end{array}$} & \multirow{2}{*}{$\begin{array}{l}\text { sampled during } \\
\text { a bloom; P lim- } \\
\text { itation }\end{array}$} & \multirow[t]{2}{*}{ Sahara dust } & 500 & $\uparrow 3.3$-fold & & $\downarrow$ & $\uparrow$ & $\uparrow$ & $\uparrow$ & \multirow{2}{*}{$\begin{array}{l}\mathrm{P} \text { and other nu- } \\
\text { trients in Saha- } \\
\text { ran dust have a } \\
\text { fertilization ef- } \\
\text { fect }\end{array}$} & \multirow{2}{*}{$\begin{array}{l}\text { Lekunberr } \\
\text { et al. } \\
(2010)\end{array}$} \\
\hline & & & 50 & $\uparrow 1.5$-fold & & $\downarrow$ & $\uparrow$ & & & & \\
\hline \multirow{2}{*}{$\begin{array}{l}\text { Northwest } \\
\text { Mediterranean }\end{array}$} & \multirow{2}{*}{$\begin{array}{l}\text { well stratified; } \\
\text { low-nutrient } \\
\text { low-Chl }\end{array}$} & Sahara dust & 0.25 & $\rightarrow$ & \multicolumn{5}{|c|}{ benefit eukaryotic populations } & \multirow[b]{2}{*}{$\begin{array}{l}\text { Atmospheric } \\
\text { supply of nu- } \\
\text { trients during } \\
\text { stratified period } \\
\text { significantly } \\
\text { altered the } \\
\text { community } \\
\text { structure }\end{array}$} & \multirow{2}{*}{$\begin{array}{l}\text { Bonnet } \\
\text { et al. } \\
(2006)\end{array}$} \\
\hline & & $\begin{array}{l}\text { Anthropogenic } \\
\text { particles }\end{array}$ & 0.01 & $\uparrow$ & \multicolumn{5}{|c|}{ enhance mainly pico- and nano-phytoplankton } & & \\
\hline $\begin{array}{l}\text { Northeast } \\
\text { Atlantic }\end{array}$ & $\begin{array}{l}\text { variable proper- } \\
\text { ties; intermedi- } \\
\text { ate DFe conc. }\end{array}$ & Sahara dust & 1.34 & $\uparrow<2$-fold & \multicolumn{3}{|c|}{$\uparrow$} & $\uparrow$ & $\rightarrow$ & $\begin{array}{l}\text { Sahara dust sup- } \\
\text { ply bioavailable } \\
\mathrm{Fe} \text { and relieve } \\
\text { Fe limitation }\end{array}$ & $\begin{array}{l}\text { Blain } \\
\text { et al. } \\
(2004)\end{array}$ \\
\hline $\begin{array}{l}\text { Tropical North } \\
\text { Atlantic }\end{array}$ & $\begin{array}{l}\text { oligotrophic; } \\
\text { N limitation }\end{array}$ & $\begin{array}{l}\text { Sahara surface } \\
\text { soils }\end{array}$ & $0.5-2$ & $\uparrow$ or $\rightarrow$ & \multicolumn{5}{|c|}{ dust relieve $\mathrm{P}$ and $\mathrm{Fe}$ co-limitation of diazotrophy in the region } & $\begin{array}{l}\text { Saharan dust } \\
\text { addition stim- } \\
\text { ulated nitrogen } \\
\text { fixation by sup- } \\
\text { plying both } \mathrm{Fe} \\
\text { and } \mathrm{P} \text {. }\end{array}$ & $\begin{array}{l}\text { Mills } \\
\text { et al. } \\
(2004)\end{array}$ \\
\hline $\begin{array}{l}\text { Central North } \\
\text { Atlantic }\end{array}$ & $\begin{array}{l}\text { oligotrophic; } \\
\text { nutrient } \\
\text { limitation }\end{array}$ & $\begin{array}{l}\text { Sahara } \\
\text { soils/aerosol }\end{array}$ & 2 & $\uparrow$ & \multicolumn{5}{|c|}{ biological responses were similar to $\mathrm{Fe}$ addition } & $\begin{array}{l}\text { Fe supplied by } \\
\text { dust increases } \\
\text { the rate of } \\
\text { nitrate con- } \\
\text { sumption, which } \\
\text { is important in } \\
\text { controlling the } \\
\text { dynamics of } \\
\text { spring bloom }\end{array}$ & $\begin{array}{l}\text { Moore } \\
\text { et al. } \\
(2006)\end{array}$ \\
\hline $\begin{array}{l}\text { Central } \\
\text { Atlantic }\end{array}$ & oligotrophic & Sahara dust & 2 & $\uparrow$ & $\downarrow$ & $\downarrow$ & $\uparrow$ & & & $\begin{array}{l}\text { The response of } \\
\text { microbial plank- } \\
\text { ton depends on } \\
\text { the ecosystem's } \\
\text { degree of olig- } \\
\text { otrophy and was } \\
\text { modulated by } \\
\text { the competition } \\
\text { for nutrients } \\
\text { between phy- } \\
\text { toplankton and } \\
\text { heterotrophic } \\
\text { bacteria. }\end{array}$ & $\begin{array}{l}\text { Marañón } \\
\text { et al. } \\
(2010)\end{array}$ \\
\hline \multirow{2}{*}{$\begin{array}{l}\text { Northwest } \\
\text { Mediterranean } \\
\text { coast }\end{array}$} & \multirow{2}{*}{$\begin{array}{l}\text { After spring } \\
\text { bloom; } \\
\text { P limitation }\end{array}$} & Sahara dust & 50 & $\rightarrow$ & & & & $\uparrow$ & & Dust pulses & Romero \\
\hline & & & 500 & $\uparrow 10$-fold & & & & $\uparrow$ & & $\begin{array}{l}\text { spring bloom } \\
\text { can regenerate } \\
\text { the bloom, and } \\
\text { change the } \\
\text { phytoplankton } \\
\text { dynamics. }\end{array}$ & $(2011)$ \\
\hline
\end{tabular}

$\uparrow:$ Increase; $\downarrow$ : decrease; $\rightarrow$ : no significant change; abund.: abundance 

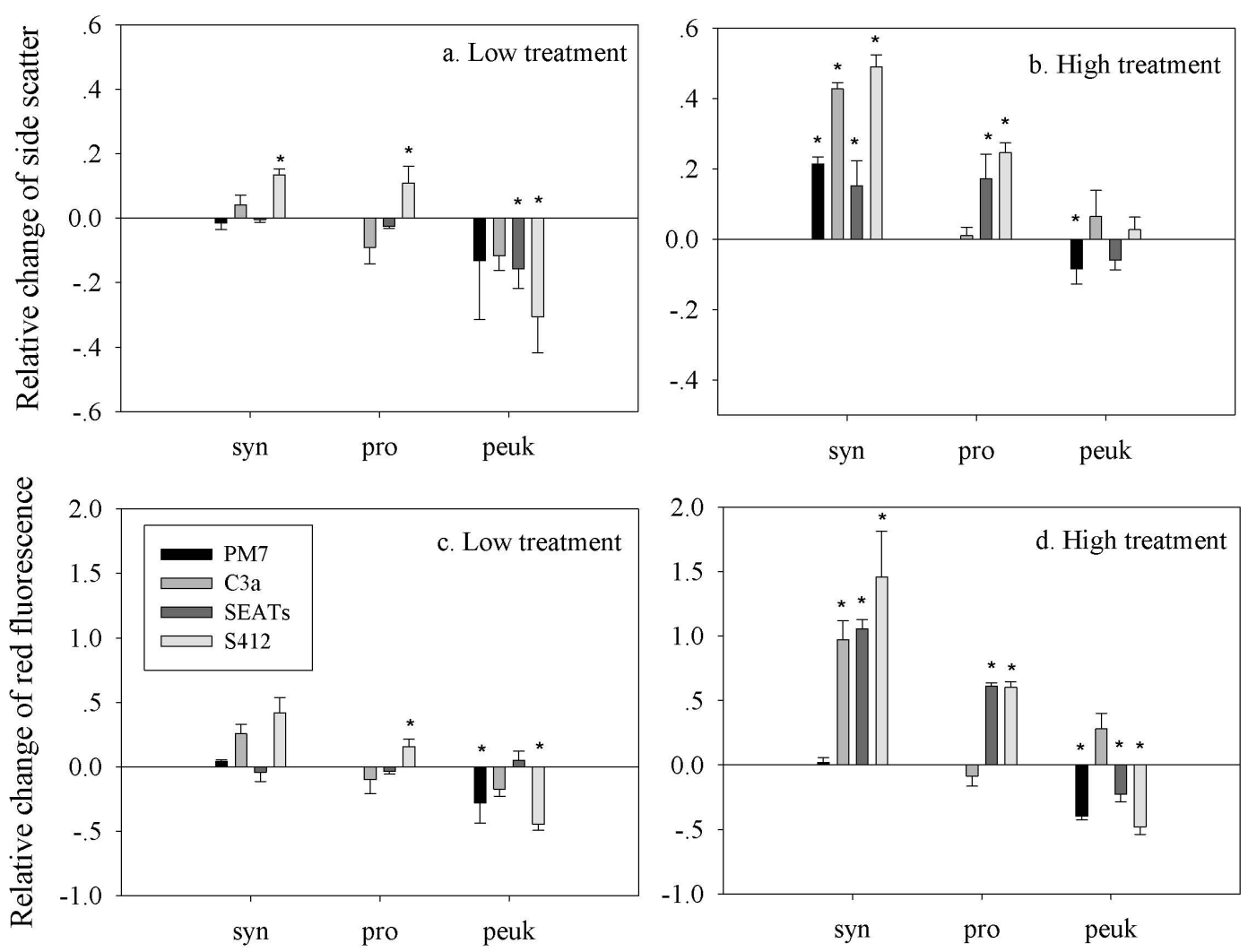

Fig. 8. Responses of picoplankton normalized (a, b) side scatter signal, and (c, d) red fluorescence to the EA aerosol enrichment in Experiment 1 and 2 . The data were measured at $72 \mathrm{~h}$. Relative changes $(\%)$ were calculated as $100 \times(\mathrm{A}-\mathrm{C}) / \mathrm{C}(\mathrm{A}$ and $\mathrm{C}$ are mean values of the variable in the aerosol treatments and control, respectively). Error bars represent the propagation of the standard deviation of the measurements in the control and treatments. Asterisks indicate statistically significant mean values $(p<0.05)$ compared with the controls.

only about $0.2-0.3 \mathrm{nM}$, which is similar to that in the central North Pacific (Wu et al., 2003). Some studies suggested that even though the total phytoplankton production was not $\mathrm{Fe}$ limited or ambient concentrations of dissolved Fe were relatively high $(0.40-0.45 \mathrm{nM})$, phytoplankton community structure could still be affected by the availability of $\mathrm{Fe}$ (Blain et al., 2004; Vuorio et al., 2005). It is also possible that other aerosol-derived components (e.g. trace metals other than $\mathrm{Fe}$, organic nutrients) introduced by aerosols or synergistic interactions between different elements played an important role in the process.

In addition to the stimulating effect of aerosol-derived nutrient supply on phytoplankton growth, the possible promotion of cell removing process by aerosol nutrients should also be taken into account when interpreting the results of the bioassay experiments. In Experiment 1, we did not observe significant changes of total Chl $a$ concentration in the low EA aerosol treatment, which is inconsistent with the previous result of linear increase of $\mathrm{Chl} a$ with increasing concentration of fresh Saharan dust addition that was demonstrated by Herut et al. (2005). At the same time, the abundance of HNF increased significantly in the Low treatment. We believe that the lack of biomass accumulation may be at- tributed to enhanced protistan grazing, which has been well established as a significant, or even the dominant, source of mortality for phytoplankton (from small picophytoplankton to large chain-forming diatoms), bacteria and other protists in aquatic microbial food webs (Sherr and Sherr, 2002). Nutrient enrichment can cause a quick improvement in the physiological characters (e.g. increases in cell size and cellular Chl content) of phytoplankton cell (Cavender-Bares et al., 2001) and consequently stimulate microzooplankton grazing on prey with improved food quality (Landry et al., 2000; Worden and Binder, 2003). Therefore, it is possible that low level of aerosol enrichment in this study was not sufficient to cause phytoplankton biomass accumulation, but instead it resulted in enhanced grazing loss due to improved cellular physiology. Such phenomenon has also been observed in other studies (e.g. Romero et al., 2011). The balance of enhanced growth and removing processes in response to different amount of aerosol events could affect phytoplankton community structures and physiological characters. 


\subsection{Different responses of pico- and micro-phytoplankton and among different taxa}

There was a clear change in phytoplankton assemblages in response to the EA aerosol enrichment (see Figs. 2-5). Generally, phytoplankton of all size fractions were stimulated, but the effect on picophytoplankton was not as pronounced as that on microphytoplankton at most stations, inducing a phytoplankton size and composition shift. According to both pigment and microscopic data, the large diatoms and haptophytes benefited the most from aerosol deposition. This result is consistent with the observations of many nutrient enrichment experiments, which showed that diatoms become the dominant phytoplankton after the addition of $\mathrm{N}$ or $\mathrm{Fe}$ (Vuorio et al., 2005; Boyd et al., 2007), due to the ability of better equipped and rapid response to the injections of new nutrients (Goldman, 1993; Zubkov et al., 1998) and escaping grazing pressure (Boyd et al., 2007). Some species with high growth capability under enhanced nutrient availability, e.g. Chaetoceros spp., Pseudonitzchia spp., Guinardia spp., Thalassionema spp., and Skeletonema spp., prevailed after aerosol addition.

Small autotrophs are more capable of meeting their nutrient demand in oligotrophic environments than larger eukaryotic species such as diatoms, and are expected to thrive in nutrient-limited ecosystems (Chisholm, 1992; Raven, 1998). In the oligotrophic SCS, the smallest organisms, e.g. picocyanobacteria, dominated the autotrophic assemblages, and they were not strongly affected by EA aerosol. The three picoplankton groups displayed very different responses to the aerosol enrichment due to their different physiological and genetic characteristics. Generally, the abundances of Prochlorococcus and Synechococcus were not promoted by high concentrations of aerosol leachate, possibly because of pronounced grazing or aerosol-derived trace metal toxicity. Picocyanobacteria have been reported to be particularly sensitive to some trace metals. For instance, the growth and cell division of Synechococcus could be severely inhibited in the copper-contaminated environment with free $\left[\mathrm{Cu}^{2+}\right]>10^{-12} \mathrm{moll}^{-1}$ (Brand et al., 1986; Bruland et al., 1991; Mann et al., 2002). Prochlorococcus have been reported lacking the ability of utilizing nitrate (Rocap et al., 2003). However, the side scatter and red fluorescence of Prochlorococcus, which are the indicators of cellular carbon and Chl $a$ contents (see details in Sect. 4.4), increased when the seawater was enriched by high concentrations of aerosol, indicating that their physiological condition improved. It is plausible to speculate that enhanced microzooplankton grazing in responding to improved prey quality was the main cause for the decline of Prochlorococcus abundance (Mann and Chisholm, 2000). Consistent with our experiment at the shelf station C3a, declines in Prochlorococcus abundance have also been observed in Mediterranean waters, Red Sea and Atlantic Ocean in response to Saharan dust and African aerosols (Herut et al., 2005; Payan et al., 2009; Marañón et al., 2010; see Table 3). Abundance of picoeukaryotes increased significantly in aerosol enriched waters, suggesting their increased ability to adapt to nutrient replete environments compared with picocyanobacteria.

\subsection{Aerosol effects on physiological states of phytoplankton}

The physiological variables of phytoplankton populations in SCS also demonstrated a marked response to the EA aerosol input. The cellular carbon and $\mathrm{Chl} a$ contents, indicated by normalized side scatter and red fluorescence, respectively, represent the energy content and energy supply ability of the cell (Geider, 1987). The change of cellular carbon and $\mathrm{Chl} a$ content of picoplankton was different from their abundance change. For Prochlorococcus and Synechococcus, cellular carbon content and cellular Chl $a$ content both exhibited immediate and significant enhancement after high aerosol addition in most experiments, indicating that physiological stress was relieved by aerosol nutrients. Such responses are consistent with the high $\mathrm{N}$ requirement and low $\mathrm{P}$ requirement for the synthesis of pigment-protein macromolecular complexes (Geider and La Roche, 2002). Community composition change of Prochlorococcus and Synechococcus in response to aerosol enrichment may also be the reason for the increase of cellular carbon and Chl $a$. Enhanced microzooplankton grazing mortality, selective ingestion in favor of cells of a larger size and higher nutrient content (Gonzalez et al., 1990; Sherr and Sherr, 1994; Worden and Binder, 2003), or prevalence of small species of picoeukaryotes are the most likely reason for the observed side scatter and red fluorescence decreases of picoeukaryotes after aerosol addition. The ability of alleviating nutrient limitation by the EA aerosol can also be demonstrated by the significantly higher photochemical efficiency of PSII (Fv/Fm) after high aerosol addition (Kolber et al., 1994; Berges et al., 1996).

\subsection{Ecological and biogeochemical implications and future prospects}

The shift of phytoplankton biomass, size and species composition in response to the high level of EA aerosol has broad implications for the understanding of atmosphere-ocean interactions in SCS from a biogeochemical point of view. As a typical oligotrophic subtropical marginal sea of the North Pacific, SCS is viewed as a weak carbon source (Zhai et al., 2005). The community structure, especially the size structure of the primary producers and the microbial food web, plays a very important role in determining the oceanic carbon flux (Boyd and Newton, 1999). In SCS, the phytoplankton community is dominated by picophytoplankton, which contribute less to direct vertical carbon export due to the small size and low sinking rate (Hagstrom et al., 1988; Lomas and Moran, 2011). Diatoms, though make up only a small fraction of the total phytoplankton production, are responsible for the 


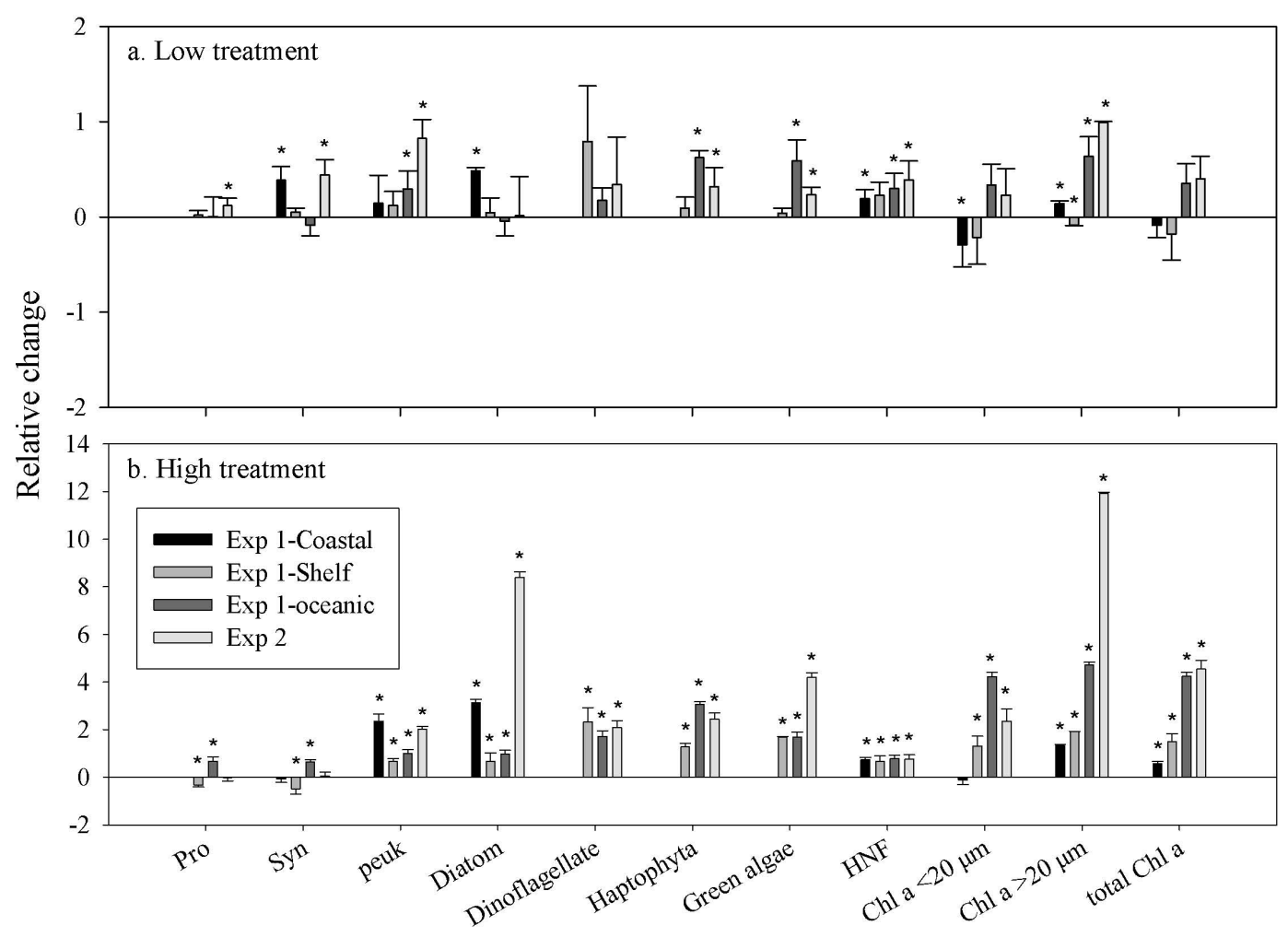

Fig. 9. Responses of Chl $a$, protists and phytoplankton community structure in the Low (a) and High (b) treatment in Experiment 1 and 2. Relative changes $(\%)$ were calculated as $100 \times(\mathrm{A}-\mathrm{C}) / \mathrm{C}$ (A and $\mathrm{C}$ are mean values of the variables in the aerosol treatments and control, respectively). Error bars represent the propagation of the standard deviation of the measurements in the control and treatments. Asterisks indicate statistically significant mean values $(p<0.05)$ compared with the controls. Concentration of the marker pigments peridinin, neoxanthin and 19'-hexa-noyloxyfucoxanthin measured by HPLC were used to indicate the biomass of dinoflagellates, green algae and haptophyta, respectively.

majority of export production in open ocean environments (Smetacek, 1985; Goldman, 1993). Since a large amount of aerosol loading results in the bloom of large phytoplankton (especially diatoms) it can shift the phytoplankton to a large cell dominated community and potentially enhance the export fluxes of carbon through sinking of senescent cells (Miller et al., 1991; Goldman, 1993; Boyd et al., 1998). At the same time, the aerosol enrichment also enhances the physiological conditions of the autotrophs, and may stimulate zooplankton grazing activities, which may also increase the carbon export through downward fluxes of fecal pellets. Both the structural and physiological shifts are likely to result in elevated vertical carbon export, drawdown of $p \mathrm{CO}_{2}$ and finally change the carbon budget in SCS. Besides the autotrophic phytoplankton, we also observed apparent changes in bacterial composition (C. Guo et al., unpublished data), as well as significant increase of protist abundance, further signifying the potential effect of the EA aerosol to the biogeochemical cycle in SCS. However, the effect of aerosol on marine ecosystem could be highly variable among different regions due to the complex interplay between aerosol supply and the planktonic communities. In fact, the degree of phytoplankton biomass and community structural changes depends on many confounding factors, including the aerosol source and composition, the deposition rate and mode (single pulse vs. continuous input) and the hydrographic features of the region where aerosols deposit. For example, as observed in this study, in the intermediate oligotrophic SCS, the atmospheric events with low levels of aerosol deposition may not induce apparent Chl $a$ accumulation (Fig. 9). By conducting experiments along a nutrient gradient, we have demonstrated that the aerosol deposition plays an increasingly important role in total biomass accumulation in oligotrophic oceanic water compared with nutrient-rich coastal region, supported by the largest increase $(\sim 3.5$-fold increase compared with control) of total Chl $a$ at the oligotrophic deep ocean station SEATs among three one-time aerosol addition experiments. However, on the scale of ultra-oligotrophic to oligotrophic regions, as suggested by a recent study (Maranón et al., 2010), the phytoplankton assemblage became less responsive to the dust inputs with the increase of oligotrophic degrees due to competition for nutrients with bacteria. In addition, by comparing the results of Experiment 1 and Experiment 2 , which were conducted at similar oceanic waters, 
continuous aerosol loading events may have a stronger impact on the community structure of phytoplankton compared with the episodic one-time aerosol deposition event at the same location.

It needs to be pointed out that vertical mixing and deep water advection are usually enhanced simultaneously accompanying aerosol deposition events, especially the wind-induced episodic aerosol transport. In SCS, the maximum aerosol loading is always accompanied with the northeast monsoon that prevails in winter. Thus, in real situations, the influence of atmospheric events is a combined effect of both hydrodynamic and atmospheric processes. Some studies have suggested that compared with atmospheric aerosol deposition, the wind-driven deep water advection is probably the main reason for phytoplankton blooms in the ocean (Boyd et al., 1998; Hung et al., 2009). Besides, fast dispersion of aerosol nutrient, high specific rates of grazing and sinking processes may produce much higher nutrient demands in situ than growth of populations in microcosm enrichment bioassays. Hence, with the same amount of aerosol deposition, the effect on real conditions may not be as strong as during the in vitro experiments. Nevertheless, Romero et al. (2011) reported that dust inputs accompanied by turbulence might magnify the effects. In our case, considering the intense and large-scale of the northeast monsoon in winter and oligotrophic nature of SCS, we believe that the loading of highly anthropogenic-derived EA aerosol plays an important role in potentially affecting the primary production, planktonic food web dynamics, and carbon flux in SCS.

\section{Conclusions}

In summary, our study demonstrated for the first time the detailed interactions between EA aerosol deposition and marine phytoplankton community dynamics in SCS. Generally, the EA aerosol deposition enhanced the photosynthetic efficiency and biomass and shifted the dominant taxa of phytoplankton assemblages from picophytoplankton to microphytoplankton, especially large diatoms at most stations. Picocyanobacteria, Prochlorococcus and Synechococcus, showed sensitivity to the EA aerosols and their abundance decreased when the aerosol addition was high in most experiments. Under high levels of aerosol loading, the phytoplankton composition shift was apparent, with cellular physiological conditions remarkably improved and more Chl $a$ and carbon biomass accumulated. However, under low levels of aerosol loading, the composition shift was less remarkable and biomass accumulation was not apparent, suggesting that the stimulation of phytoplankton growth by bioavailable nutrients in the aerosol is counterbalanced by increased biomass loss, possibly due to enhanced grazing mortality. Moreover, continuous atmospheric deposition could lead to a more conspicuous effect compared to episodic short-time atmospheric events. The pronounced increase of microphy- toplankton biomass and strong assemblage shift toward diatoms resulted from large EA aerosol input may enhance the efficiency of the biological pump. Therefore, a better understanding of the impact of nutrient inputs from EA aerosols on the marine photosynthetic community and its ecological and biogeochemical consequences are crucial for predicting the oceanic carbon cycle in climate change models.

Acknowledgements. We sincerely thank the captain and crew of the R/V Dongfanghong2, the chief scientist Minhan Dai, as well as the students and staff who joined this cruise, for their support during the work at sea. We also thank Minhan Dai for providing in situ inorganic nutrient data and Jianyu Hu for providing the CTD data. The critical comments from all reviewers have significantly improved the quality of the paper. This study was supported by the National Basic Research Program ("973" Program) of China through Grant No. 2009CB421203 and the Research Grants Council of Hong Kong GRF grants (661809 and 661610) awarded to H. Liu. Support from the TUYF Charitable Trust (TUYF10SC08) is also acknowledged.

Edited by: K. Suzuki

\section{References}

Aguilar-Islas, A. M., Wu, J., Rember, R., Johansen, A. M., and Shank, L. M.: Dissolution of aerosol-derived iron in seawater: Leach solution chemistry, aerosol type, and colloidal iron fraction, Mar. Chem., 120, 25-33, 2010.

Akimoto, H.: Global air quality and pollution, Science, 302, 17161719, 2003.

Baker, A. R., Kelly, S. D., Biswas, K. F., Witt, M., and Jickells, T. D.: Atmospheric deposition of nutrients to the Atlantic Ocean, Geophys. Res. Lett., 30, 2296-2299, 2003.

Berges, J. A., Charlebois, D. O., Mauzerall, D. C., and Falkowski, P. G.: Differential effects of nitrogen limitation on photosynthetic efficiency of photosystems I and II in microalgae, Plant Physiol., 110, 689-696, 1996.

Blain, S., Guieu, C., Claustre, H., Leblanc, K., Moutin, T., Queguiner, B., Ras, J., and Sarthou, G.: Availability of iron and major nutrients for phytoplankton in the northeast Atlantic Ocean, Limnol. Oceanogr., 49, 2095-2104, 2004.

Bonnet, S., Guieu C., Chiaverini, J., Ras J., and Stock, A.: Effect of atmospheric nutrients on the autotrophic communities in a low nutrient, low chlorophyll system, Limnol. Oceanogr., 50, 18101819, 2006.

Boyd, P. W. and Newton, P. P.: Does planktonic community structure determine downward particulate organic carbon flux in different oceanic provinces?, Deep-Sea Res. Pt. I, 46, 63-91, 1999.

Boyd, P. W., Wong, C. S., Merrill, J., Whitney, Snow, F., J., Harrison, P. J., and Gower, J.: Atmospheric iron supply and enhanced vertical carbon flux in the NE subarctic Pacific: Is there a connection? Global Biogeochem. Cy., 12, 429-441, 1998.

Boyd, P. W., Jickells, T., Law, C. S., Blain, S., Boyle, E. A., Buesseler, K. O., Coale, K. H., Cullen, J. J., De Baar, H. J. W., Follows, M., Harvey, M., Lancelot, C., Levasseur, M., Owens, N. P. J., Pollard, R., Rivkin, R. B., Sarmiento, J., Schoemann, V., Smetacek, V., Takeda, S., Tsuda, A., Turner, S., and Watson, A. 
J.: Mesoscale iron enrichment experiments 1993-2005: Synthesis and future directions, Science, 315, 612-617, 2007.

Brand, L. E., Sunda, W. G., and Guillard, R. R. L.: Reduction of marine phytoplankton reproduction rates by copper and cadmium, $\mathrm{J}$. Exp. Mar. Biol. Ecol., 96, 225-250, 1986.

Bruland K. W., Donut, J. R., and Hutchins, D. A.: Interactive influences of bioactive trace metals on biological production in oceanic waters, Limnol. Oceanogr., 36, 1555-1577, 1991.

Cavender-Bares, K. K., Karl, D. M., and Chisholm, S. W.: Nutrient gradients in the western North Atlantic Ocean: relationship to microbial community structure and comparison to patterns in the Pacific Ocean, Deep-Sea Res. Pt. I, 48, 2373-2395, 2001.

Chameides, W. L., Yu, H., Liu, S. C., Bergin, M., Zhou, X., Mearns, L., Wang, G., Kiang, C. S., Saylor, R. D., Luo, C., Huang, Y., Steiner, A., and Giorgi, F.: Case study of the effects of atmospheric aerosols and regional haze on agriculture: An opportunity to enhance crop yields in China through emission controls, P. Natl. Acad. Sci. USA, 96, 13626-13633, 1999.

Chen, Y. L., Chen, H.-Y., Karl, D. M., and Takahashi, M.: Nitrogen modulates phytoplankton growth in spring in the South China Sea, Cont. Shelf Res., 24, 527-541, 2004.

Chisholm, S. W.: Phytoplankton size, in: Primary Productivity and Biogeochemical Cycles in the Sea, edited by: Falkowski, P. G. and Woodhead, A. D., Plenum Press, New York, 1992.

Cohen, D. D., Garton, D., Stelcer, E., Hawas, O., Wang, T., Poon, S., Kim, J., Choi, B. C., Oh, S. N., Shin, H.-J., Ko, M. Y., and Uematsu, M.: Multielemental analysis and characterization of fine aerosols at several key ACE-Asia sites, J. Geophys. Res., 109, D19S12, doi:10.1029/2003jd003569, 2004.

Doney, S. C., Mahowald, N., Lima, I., Feely, R. A., Mackenzie, F. T., Lamarque, J. F., and Rasch, P. J.: Impact of anthropogenic atmospheric nitrogen and sulfur deposition on ocean acidification and the inorganic carbon system, P. Natl. Acad. Sci. USA, 104, 14580-14585, 2007.

Duce, R. A. and Tindale, N. W.: Atmospheric transport of iron and its deposition in the ocean, Limnol. Oceanogr., 36, 1715-1726, 1991.

Duce, R. A., Liss, P. S., Merrill, J. T., Atlas, E. L., Buat-Menard, P., Hicks, B. B., Miller, J. M., Prospero, J. M., Arimoto, R., Church, T. M., Ellis, W., Galloway, J. N., Hansen, L., Jickells, T. D., Knap, A. H., Reinhardt, K. H., Schneider, B., Soudine, A., Tokos, J. J., Tsunogai, S., Wollast, R., and Zhou, M.: The atmospheric input of trace species to the world ocean, Global Biogeochem. Cy., 5, 193-259, 1991.

Duce, R. A., Laroche, J., Altieri, K., Arrigo, K. R., Baker, A. R., Capone, D. G., Cornell, S., Dentener, F., Galloway, J., Ganeshram, R. S., Geider, R. J., Jickells, T., Kuypers, M. M., Langlois, R., Liss, P. S., Liu, S. M., Middelburg, J. J., Moore, C. M., Nickovic, S., Oschlies, A., Pedersen, T., Prospero, J., Schlitzer, R., Seitzinger, S., Sorensen, L. L., Uematsu, M., U1loa, O., Voss, M., Ward, B., and Zamora, L.: Impacts of atmospheric anthropogenic nitrogen on the open ocean, Science, 320, 893-897, 2008.

Elser, J. J., Andersen, T., Baron, J. S., Bergstrom, A. K., Jansson, M., Kyle, M., Nydick, K. R., Steger, L., and Hessen, D. O.: Shifts in lake N:P stoichiometry and nutrient limitation driven by atmospheric nitrogen deposition, Science, 326, 835-837, 2009.

Falkowski, P. G.: Evolution of the nitrogen cycle and its influence on the biological sequestration of $\mathrm{CO}_{2}$ in the ocean, Nature, 387,
272-275, 1997.

Falkowski, P. G., Barber, R. T., and Smetacek, V.: Biogeochemical controls and feedbacks on ocean primary production, Science, 281, 200-206, 1998.

Furuya, K., Hayashi, M., and Yabushita, Y.: HPLC Determination of phytoplankton pigments using N, N-Dimethylformamide, J. Oceanogr., 54, 199-203, 1998.

Gao, Y., Aromoto, R., Duce, R. A., Zhang, X. Y., Zhang, G. Y., An, Z. S., Chen, L. Q., Zhou, M. Y., and Gu, D. Y.: Temporal and spatial distribution of dust and its deposition to the China Sea, Tellus, 49B, 172-189, 1997.

Geider, R. J.: Light and temperature dependence of the carbon to chlorophyll a ratio in microalgae and cyanobacteria: implications for physiology and growth of phytoplankton, New Phytol., 106, 1-34, 1987.

Geider, R. J. and Roche, J. L.: Redfield revisited: Variability of $\mathrm{C}: \mathrm{N}: \mathrm{P}$ in marine microalgae and its biochemical basis, Eur. J. Phycol., 37, 1-17, 2002.

Goldman, J. C.: Potential role of large oceanic diatoms in new primary production, Deep-Sea Res. Pt. I, 40, 159-168, 1993.

Gong, G.-C., Chang, J., and Wen, Y.-H.: Estimation of annual primary production in the Kuroshio waters northeast of Taiwan using a photosynthesis-irradiance model, Deep-Sea Res. Pt. I, 46, 93-108, 1999.

Gong, S. L., Zhang, X. Y., Zhao, T. L., McKendry, I. G., Jaffe, D. A., and Lu, N. M.: Characterization of soil dust aerosol in China and its transport and distribution during 2001 ACE-Asia: 2. Model simulation and validation, J. Geophys. Res., 108, 4262, doi:10.1029/2002jd002633, 2003.

Gonzalez, J. M., Sherr, E. B., and Sherr, B. F.: Size-selective grazing on bacteria by natural assemblages of estuarine flagellates and ciliates, Appl. Environ. Microbiol., 56, 583-589, 1990.

Guieu, C., Bozec, Y., Blain, S., Ridame, C., and Leblond, G. S. N.: Impact of high Saharan dust inputs on dissolved iron concentrations in the Mediterranean Sea, Geophys. Res. Lett., 29, 1911-1914, 2002.

Hagstrom, A., Azam, F., Andersson, A., Wikner, J., and Rassoulzadegan, F.: Microbial loop in an oligotrophic pelagic marine ecosystem: possible roles of cyanobacteria and nanoflagellates in the organic fluxes, Mar. Ecol.-Prog. Ser., 49, 171-178, 1988.

Herut, B., Zohary, T., Krom, M., Mantoura, R., Pitta, P., Psarra, S., Rassoulzadegan, F., Tanaka, T., and Fredethingstad, T.: Response of East Mediterranean surface water to Saharan dust: Onboard microcosm experiment and field observations, Deep-Sea Res. Pt. II, 52, 3024-3040, 2005.

Ho, T.-Y., Wen, L.-S., You, C.-F., and Lee, D.-C.: The trace metal composition of size-fractionated plankton in the South China Sea: Biotic versus abiotic sources, Limnol. Oceanogr., 52, 17761788, 2007.

Hsu, S.-C., Wong, G. T. F., Gong, G.-C., Shiah, F.-K., Huang, Y.T., Kao, S.-J., Tsai, F., Lung, S.-C. C., Lin, F.-J., and Lin, I.-I.: Sources, solubility, and dry deposition of aerosol trace elements over the East China Sea, Mar. Chem., 120, 116-127, 2010.

Hung, C.-C., Gong, G.-C., Chung, W.-C., Kuo, W.-T., and Lin, F.-C.: Enhancement of particulate organic carbon export flux induced by atmospheric forcing in the subtropical oligotrophic northwest Pacific Ocean, Mar. Chem., 113, 19-24, 2009. 
Jickells, T. D., An, Z. S., Andersen, K. K., Baker, A. R., Bergametti, G., Brooks, N., Cao, J. J., Boyd, P. W., Duce, R. A., Hunter, K. A., Kawahata, H., Kubilay, N., Laroche, J., Liss, P. S., Mahowald, N., Prospero, J. M., Ridgwell, A. J., Tegen, I., and Torres, R.: Global iron connections between desert dust, ocean biogeochemistry, and climate, Science, 308, 67-71, 2005.

Knap, A., Michael, A., Close, A., Ducklow, H., and Diskson, A. (Eds.): Protocols for the Joint Global Ocean Flux Study (JGOFS) core measurements, JGOFS Report Nr. 19, Vi+170 pp., (Reprint of the IOC Manuals and Guides No. 29, UNESCO 1994), 43110, 1996.

Kolber Z. S., Barber, R. T., Coale, K. H., Fitzwateri, S. E., Greene, R. M., Johnson, K. S., Lindley, S., and Falkowski, P. G.: Iron limitation of phytoplankton photosynthesis in the equatorial $\mathrm{Pa}$ cific Ocean, Nature, 371, 145-148, 1994.

Krishnamurthy, A., Moore, J. K., Zender, C. S., and Luo, C.: Effects of atmospheric inorganic nitrogen deposition on ocean biogeochemistry, J. Geophys. Res., 112, G02019, doi:10.1029/2006jg000334, 2007.

Landry, M. R., Constantinou, J., Latasa, M., Brown, S. L., Bidigare, R. R., and Ondrusek, M. E.: Biological response to iron fertilization in the eastern equatorial Pacific (IronEx II). III. Dynamics of phytoplankton growth and microzooplankton grazing, Mar. Ecol.-Prog. Ser., 201, 73-83, 2000.

Lekunberri, I., Lefort, T., Romero, E., Vazquez-Dominguez, E., Romera-Castillo, C., Marrase, C., Peters, F., Weinbauer, M., and Gasol, J. M.: Effects of a dust deposition event on coastal marine microbial abundance and activity, bacterial community structure and ecosystem function, J. Plankton Res., 32, 381-396, 2010.

Lin, I.-I., Chen, J.-P., Wong, G. T. F., Huang, C.-W., and Lien, C.-C.: Aerosol input to the South China Sea: Results from the MODerate resolution imaging spectro-radiometer, the quick scatterometer, and the measurements of pollution in the troposphere sensor, Deep-Sea Res. Pt. II, 54, 1589-1601, 2007.

Lin, I.-I., Wong, G. T. F., Lien, C.-C., Chien, C.-Y., Huang, C.-W., and Chen, J.-P.: Aerosol impact on the South China Sea biogeochemistry: An early assessment from remote sensing, Geophys. Res. Lett., 36, L17605, doi:10.1029/2009GL037484, 2009.

Liu, H., Chang, J., Tseng, C.-M., Wen, L.-S., and Liu, K. K.: Seasonal variability of picoplankton in the northern South China Sea at the SEATS station, Deep-Sea Res. Pt. II, 54, 1602-1616, 2007.

Lomas, M. W. and Moran, S. B.: Evidence for aggregation and export of cyanobacteria and nano-eukaryotes from the Sargasso Sea euphotic zone, Biogeosciences, 8, 203-216, doi:10.5194/bg8-203-2011, 2011.

Mann, E. L. and Chisholm, S. W.: Iron limits the cell division rate of Prochlorococcus in the eastern equatorial Pacific, Limnol. Oceanogr., 45, 1067-1076, 2000.

Mann, E. L., Ahlgren, N., Moffett, J. W., and Chisholm, S. W.: Copper toxicity and cyanobacteria ecology in the Sargasso Sea, Limnol. Oceanogr., 47, 976-988, 2002.

Martin, J. H.: Glacial-interglacial $\mathrm{CO}_{2}$ change: the iron hypothesis, Paleoceanograogy, 5, 1-13, 1990.

Martin, J. H., Gordon, R. M., Fitzwater, S., and Broenkow, W. W.: Vertex: phytoplankton/iron studies in the Gulf of Alaska, DeepSea Res. Pt. I, 36, 649-680, 1989.

Martin, J. H., Gordon, R. M., and Fitzwater, S. E.: The case for iron, Limnol. Oceanogr., 36, 1793-1802, 1991.
Marañón, E., Fernández, A., Mouriño-Carballido, B., MartínezGarcía, S., Teira, E., Cermeño, P., Chouciño, P., Huete-Ortega, M., Fernández, E., Calvo-Díaz, A., Morán, A. X. G., Bode, A., Moreno-Ostos, E., Varela, M. M., Patey, M. D., and Achterberg, E. P.: Degree of oligotrophy controls the response of microbial plankton to Saharan dust, Limnol. Oceanogr., 55, 2339-2352, 2010.

Miller, C. B., Frost, B. W., Wheeler, P. A., Landry, M. R., Welschmeyer, N., and Powell, T. M.: Ecological dynamics in the subarctic Pacific, a possibly iron-limited ecosystem, Limnol. Oceanogr., 36, 1600-1615, 1991.

Mills, M. M., Ridame, C., Davey, M., Roche, J. L., and Geider, R. J.: Iron and phosphorus co-limit nitrogen fixation in the eastern tropical North Atlantic, Nature, 429, 292-294, 2004.

Moore, C. M., Mills, M. M., Milne, A., Langlois, R., Achterberg, E. P., Lochte, K., Geider, R. J., and La Roche, J.: Iron limits primary productivity during spring bloom development in the central North Atlantic, Glob. Change Biol., 12, 626-634, 2006.

Neuer, S., Torres-Padrón, M. E., Gelado-Caballero, M. D., Rueda, M. J., Hernández-Brito, J., Davenport, R., and Wefer, G.: Dust deposition pulses to the eastern subtropical North Atlantic gyre: Does ocean's biogeochemistry respond?, Global Biogeochem. Cy., 18, GB4020, doi:10.1029/2004gb002228, 2004

Olaizola, M., Geider, R. J., Harrison, W. G., Graziano, L. M., Ferrari, G. M., and Schlittenhardt, P. M.: Synoptic study of variations in the fluorescence-based maximum quantum efficiency of photosynthesis across the North Atlantic Ocean, Limnol. Oceanogr., 41, 755-765, 1996.

Olson, R. J., Zettler, E. R., and Durand, M. D.: Phytoplankton analysis using flow cytometry, in: Handbook of methods in aquatic microbial ecology, edited by: Kemp, P. F., Sherr, B. F., Sherr, E. B., and Cole, J. J., Lewis, 175-186, 1993.

Onitsuka, G., Uno, I., Yanagi, T., and Yoon, J. H.: Modeling the effects of atmospheric nitrogen input on biological production in the Japan Sea, J. Oceanogr., 65, 433-438, 2009.

Paerl, H. W.: Coastal eutrophication and harmful algal blooms: Importance of atmospheric deposition and groundwater as "new" nitrogen and other nutrient sources, Limnol. Oceanogr., 42, 1154-1165, 1997.

Paytan, A., Mackey, K. R. M., Chen, Y., Lima, I. D., Doney, S. C., Mahowald, N., Labiosa, R., and Post, A. F.: Toxicity of atmospheric aerosols on marine phytoplankton, P. Natl. Acad. Sci. USA, 106, 4601-4605, 2009.

Raven, J. A.: Small is beautiful: the picophytoplankton, Funct. Ecol., 12, 503-513, 1998.

Ridame, C. and Guieu, C.: Saharan input of phosphate to the oligotrophic water of the open western Mediterranean Sea, Limnol. Oceanogr., 47, 856-869, 2002.

Romero, E., Peters, F., Marrasé, C., Guadayol, Ò., Gasol, J. M., and Weinbauer, M. G.: Coastal Mediterranean plankton stimulation dynamics through a dust storm event: An experimental simulation, Estuar. Coast. Shelf. S., 93, 27-39, 2011.

Rocap, G., Larimer, F. W., Lamerdin, J., Malfatti, S., Chain, P., Ahlgren, N. A., Arellano, A., Coleman, M., Hauser, L., Hess, W. R., Johnson, Z. I., Land, M., Lindell, D., Post, A. F., Regala, W., Shah, M., Shaw, S. L., Steglich, C., Sullivan, M. B., Ting, C. S., Tolonen, A., Webb, E. A., Zinser, E. R., and Chisholm, S. W.: Genome divergence in two Prochlorococcus ecotypes reflects oceanic niche differentiation, Nature, 424, 1042-1047, 
2003.

Sherr, E. B. and Sherr, B. F.: Bacterivory and herbivory: Key roles of phagotrophic protists in pelagic food webs, Microb. Ecol., 28, 223-235, 1994.

Sherr, E. B. and Sherr, B. F.: Significance of predation by protists in aquatic microbial food webs, Anton. Leeuw. Int. J., 81, 293-308, 2002.

Smetacek, V. S.: Role of sinking in diatom life-history cycles ecological, evolutionary and geological significance, Mar. Biol., 84, 239-251, 1985.

Strickland, J. D. H. and Parsons, T. R.: A practical handbook of seawater analysis, 2nd Edn., Bull. Fish. Res. Board., 167, 201203, 1972.

Suggett, D. J., Moore, C. M., Hickman, A. E., and Geider, R. J.: Interpretation of fast repetition rate (FRR) fluorescence: signatures of phytoplankton community structure versus physiological state, Mar. Ecol.-Prog. Ser., 376, 1-19, 2009.

Sundarambal, P., Tkalich, P., and Balasubramanian, R.: Modelling the effect of atmospheric nitrogen deposition on marine phytoplankton in the Singapore Strait, Water Sci. Technol., 61, 859, doi:10.2166/wst.2010.357, 2010.

Vuorio, K., Lagus, A., Lehtimäki, J. M., Suomela, J., and Helminen, H.: Phytoplankton community responses to nutrient and iron enrichment under different nitrogen to phosphorus ratios in the northern Baltic Sea, J. Exp. Mar. Biol. Ecol., 322, 39-52, 2005.

Wong, G. T. F., Chung, S.-W., Shiah, F.-K., Chen, C.-C., Wen, L.S., and Liu, K.-K.: Nitrate anomaly in the upper nutricline in the northern South China Sea - Evidence for nitrogen fixation, Geophys. Res. Lett., 29, 2097-2100, 2002.

Worden, A. Z. and Binder, B. J.: Application of dilution experiments for measuring growth and mortality rates among Prochlorococcus and Synechococcus populations in oligotrophic environments, Aquat. Microb. Ecol., 30, 159-174, 2003.
Wu, J., Chung, S.-W., Wen, L.-S., Liu, K.-K., Chen, Y.-L. L., Chen, H.-Y., and Karl, D. M.: Dissolved inorganic phosphorus, dissolved iron, and Trichodesmium in the oligotrophic South China Sea, Global Biogeochem. Cy., 17, 1008-1020, 2003.

Zhai, W., Dai, M., Cai, W.-J., Wang, Y., and Hong, H.: The partial pressure of carbon dioxide and air-sea fluxes in the northern South China Sea in spring, summer and autumn, Mar. Chem., 96, 87-97, 2005.

Zhang, K. and Gao, H.: The characteristics of Asian-dust storms during 2000-2002: From the source to the sea, Atmos. Environ., 41, 9136-9145, 2007.

Zhang, J., Liu, S. M., Lu, X., and Huang, W. W.: Characterizing Asian wind-dust transport to the Northwest Pacific Ocean. Direct measurements of the dust flux for two years, Tellus, 45B, 335345, 1993.

Zhang, X., Zhuang, G., Guo, J., Yin, K., and Zhang, P.: Characterization of aerosol over the Northern South China Sea during two cruises in 2003, Atmos. Environ., 41, 7821-7836, 2007.

Zheng, M., Guo, Z., Fang, M., Rahn, K., and Kester, D.: Dry and wet deposition of elements in Hong Kong, Mar. Chem., 97, 124139, 2005.

Zubkov, M. V., Sleigh, M. A., Tarran, G. A., Burkill, P. H., and Leakey, R. J. G.: Picoplankton community structure on an Atlantic transect from $50^{\circ} \mathrm{N}$ to $50^{\circ} \mathrm{S}$, Deep-Sea Res. Pt. I, 45, 13391355, 1998.

Zubkov, M. V., Burkill, P. H., and Topping, J. N.: Flow cytometric enumeration of DNA-stained oceanic planktonic protists, J. Plankton. Res., 29, 79-86, 2007. 